\title{
Combining hybrid cars and synthetic fuels with electricity generation and carbon capture and storage
}

\author{
Oscar van Vliet ${ }^{\mathrm{a}, \mathrm{b}, *}$, Machteld van den Broek ${ }^{\mathrm{a}}$, Wim Turkenburg ${ }^{\mathrm{a}}$, André Faaij ${ }^{\mathrm{a}}$ \\ a Copernicus Institute, Utrecht University, Heidelberglaan 2, 3584 CS Utrecht, The Netherlands \\ b International Institute of Applied Systems Analysis, Schlossplatz 1, A-2361 Laxenburg, Austria
}

\section{A R T I C L E I N F O}

\section{Article history:}

Received 18 June 2010

Accepted 22 September 2010

Available online 20 October 2010

Keywords:

CCS

Electric car

Biofuel

\begin{abstract}
A B S T R A C T
We examined the co-evolution of the transportation, and electricity and heat generation sectors in the Netherlands until 2040 using a MARKAL bottom-up cost optimisation model.

All scenario variants investigated indicate a switch away from crude oil-based diesel and petrol for transportation. Lowest overall $\mathrm{CO}_{2}$ abatement cost is achieved by accommodating transportation first and using relatively expensive options for emissions reduction in electricity generation if needed.

Biomass and carbon capture and storage (CCS) are used to full potential. Transportation $\mathrm{CO}_{2}$ emissions are reduced by switching to ethanol or bio-based synthetic fuels combined with CCS, and series hybrid cars if needed. Depending on the availability of biomass and carbon storage capacity, electricity is produced from biomass, coal with CCS, or wind complemented with natural gas. Indirect greenhouse gas emissions rise to $34-54 \%$ of national emissions in 2040.

The difference in annual investment required between the scenario variants with and without $\mathrm{CO}_{2}$ emissions reductions of $68 \%$ by 2040 is $4-7$ billion euro/year, or $0.5-1.2 \%$ of projected GDP.

Investment costs are mostly determined by the cost of cars and electricity generation capacity. We observe competition for limited biomass supply and $\mathrm{CO}_{2}$ storage capacity between the transportation and power sectors.
\end{abstract}

(c) 2010 Elsevier Ltd. All rights reserved.

\section{Introduction}

Electricity and heat generation and transportation are among the largest producers of greenhouse gases (GHG) in the EU, responsible for half of total GHG emissions: $32 \%$ for energy supply and $18 \%$ for transportation (EEA, 2009a). While overall GHG emissions have been reduced in recent years, both the demand for and the GHG emissions from transportation have continued to grow (EEA, 2009a, 2009b).

In transportation, the consumption of diesel and petrol derived from crude oil is also considered problematic because of uncertainty about cost developments, lack of security of supply (Mitchell, 2006; Campbell, 2006), and local and regional air pollution (EEA, 2009b). Solutions are sought in alternatives for both fuels and drivetrains (cars). On the fuel side, possibilities exist to switch from diesel and petrol to biofuels (ethanol, biodiesel), synthetic fuels (from biomass, coal or gas), hydrogen, or electricity. On the vehicle side, possibilities exist to reduce fuel

\footnotetext{
* Corresponding author at: International Institute of Applied Systems Analysis, Schlossplatz 1, A-2361 Laxenburg, Austria.

Tel.: +432236807693.

E-mail address: vanvliet@iiasa.ac.at (O. van Vliet).
}

demand by a shift to more efficient hybrid, electric or fuel cell drivetrains.

In the electricity sector, major challenges are to fulfil growing demand and simultaneously to reduce $\mathrm{CO}_{2}$ emissions (TenneT, 2008). Potential solutions include enhanced use of renewable sources of electricity (e.g. wind, solar, and biomass), increasing the efficiency of energy conversion and end-use, and applying carbon capture and storage (CCS) technologies. This adds another challenge of integrating these technologies into the electricity system in a way that guarantees reliability of the electricity supply.

In the existing system, the electricity/heat generation sector and transport sector are largely separated. If the alternatives mentioned above come into play, these two sectors may become more intertwined because of the following:

- Resource competition: Lignocellulosic biomass (wood and grasses) can be used for both synthetic fuel and power ${ }^{1}$ production. All use of biomass competes to some degree because of land scarcity.

\footnotetext{
${ }^{1}$ In this paper, we refer to the combined electricity and heat sectors as the power sector, and electricity and heat generation as power generation.
} 
- Development of CCS: Both power plants and synthetic fuels plants can produce streams of $\mathrm{CO}_{2}$ suitable for storage. Combining these streams can make development of CCS infrastructure more attractive, but also fill up available storage capacity more quickly.

- Electricity co-production: Electricity is a major by-product in the thermochemical production of synthetic fuels and can be an input or a by-product in the production of hydrogen.

- Electricity demand: Electric cars and plug-in hybrid cars directly increase the demand for electricity and may therefore increase the need for generation capacity and grid upgrades. Batteries that can be flexibly charged can allow for more base load and intermittent electricity sources.

\subsection{Existing research}

Numerous studies have been done to explore development of the total energy system including the power and transport sectors using a computer model of national or supra-national energy systems (see e.g. UK-MARKAL model (UKERC, 2008), Hyways project (LBST, 2007), Energy Technology Perspectives (IEA, 2008a; Smekens-Ramirez Morales, 2004). However, most all of these studies address the coevolution of the power and transport sectors in a minimal way. Other studies, like the World Energy Outlook (WEO) 2009, address power and transportation without explicitly discussing interactions (IEA, 2009).

Studies that explicitly explored the interaction between the power and transport sectors still have limitations. One example is a 2006 study by the Pacific Northwest National Laboratory (Kintner-Meyer et al., 2007) investigating the impacts of using the existing idle (off-peak) capacity of the electric infrastructure in conjunction with the emerging plug-in hybrid electric vehicle (PHEV) technology. Their conclusion was that $73 \%$ of the light duty vehicle fleet ${ }^{2}$ could be supported by existing electric infrastructure for a daily drive of $53 \mathrm{~km}$ on average. They also stated that "the mix of future power plant types and technologies may change as a result of the flatter load-duration curve favouring more base-load power plants and intermittent renewable energy resources". However, this analysis did not project a mix of power plants in the future and, thus, did not analyse the consequences for costs or emissions resulting from this mix.

Using the UK MARKAL model coupled to a GIS, Strachan et al. (2008) studied scenarios for the use of hydrogen in transportation with CCS to reduce $\mathrm{CO}_{2}$ emissions, including the matching of energy supply and demand in time and space. Their conclusion was that spatial clustering of demand allows for essential economies of scale, and proximity of production sites to demand centres is preferable over pipelines. However, they did not investigate other options to attain comparable levels of $\mathrm{CO}_{2}$ emissions reductions in transportation. Using the MARKAL-NL-UU model coupled to a GIS, van den Broek et al. (2009, in press) similarly examined the development of CCS in the power sector of the Netherlands. This study focused on underground storage of $\mathrm{CO}_{2}$ from production of electricity and heat only.

Proost et al. (2009) explored the role of taxation in transport in GHG emissions reductions in the EU, and find that taxes currently do not cover all external costs. They find that GHG emissions reductions are most cheaply achieved outside transportation, but do not include plug-in or series hybrid cars.

Wise et al. (2010) explored the effect of introducing plug-in hybrid vehicles using the Minicam model. They found that plug-in

\footnotetext{
${ }^{2}$ By their definition, the light duty vehicle fleet includes cars, pickup trucks, sport utility vehicles (SUVs), and vans.
}

hybrid cars can reduce demand for biofuels but increase demand for CCS, and that stronger climate policy and limited availability of biofuels drive adoption of plug-in hybrid cars. However, they did not take other vehicle technologies into account. Ichinohe and Endo (2006) examine the vehicle mix using a MARKAL model, but use only modest GHG emissions reduction.

Using the UK MARKAL model coupled to a macro-economic model, Strachan and Kannan (2008) studied the macro-economic impact of $60 \% \mathrm{CO}_{2}$ emissions reduction in the UK. They find that demand response to mitigation costs causes a smaller increase of energy demand when carbon constraints are included when compared to standalone MARKAL. Preferred options for decarbonisation appear to be the use of coal with CCS, nuclear and wind energy. However, uncertainties in the future costs and characteristics of these technologies make it is impossible to robustly project the emergence of a dominant technology. A reduction in 2050 GDP of $0.3-1.5 \%$ was found, with the largest reduction in GDP caused by limiting technology to what is available in 2010. Transportation shifts towards biofuels, diesel- and hybrid cars in all scenarios, including baseline. Further decarbonisation is achieved using hydrogen after 2030 but only if reductions cannot be achieved in electricity generation and this is not explored in depth. Anandarajah and Strachan (in press) report use of PHEV and EV instead, as well as tradeoffs between use of biomass in power generation and in transportation.

Grahn et al. (2009) explored co-evolution between the transportation and power sectors until 2100 using the GET model. They found largely uniform mixes of fuels and cars in the short to medium term, with continuing large shares of diesel and petrol. Only after 2040 did mixes of vehicles and fuel technologies diverge. They also found that concentrated solar power and CCS delay a transition in the transportation sector in the long term, because $\mathrm{CO}_{2}$ emissions reductions can more easily be attained in electricity generation. However, their technology descriptions are generic. They also assume challenging cost reductions for batteries, hydrogen storage and fuel cells based on policy targets and manufacturer projections, which are an order of magnitude lower than the current costs. The latter also applies to Gül et al. (2009).

Hedenus et al. (2010) also used the GET model for a global study until 2100 and find that hydrogen cars are used instead of plug-in hybrids if coal with CCS is dominant, though a sufficiently low cost of batteries causes EV to be used instead. An energy system using solar or nuclear makes biofuels tends to make biofuels and hybrid cars cost-effective.

Studies that investigate the power sector usually assume constant growth rate of demand for energy services. These projections do not include major changes in trends such as a strong increase in electricity demand from transportation. Therefore, short to medium term advantages and disadvantages of, for example, a combination of CCS, renewables, and electrified transportation has not been analysed. We address these issues in combination this chapter.

\subsection{Approach and objectives}

In this chapter, we aim to explore the co-evolution of the power and transport sectors under strict $\mathrm{CO}_{2}$ emission reduction policies. Specifically, we addressed the following research questions:

- What shifts in the mix of fuels, vehicles and electricity generation capacity may emerge when we need to reduce $\mathrm{CO}_{2}$ emissions? 
- How may the power and transportation sectors co-evolve under $\mathrm{CO}_{2}$ emission reduction policies?

- How may the use of energy resources, $\mathrm{CO}_{2}$ emissions per sector, $\mathrm{CO}_{2}$ abatement costs and investment required develop over time as a result of $\mathrm{CO}_{2}$ emission reduction targets?

To investigate these questions in detail, we focus on the energy system in the Netherlands. We expand the MARKAL model for the Netherlands, a least-cost optimisation model for the energy system, with sections on transportation fuel production, biomass resources, costs and fuel consumption of vehicles, and road transportation demand. We applied this expanded model to investigate scenario variants for power and transportation that have different levels of $\mathrm{CO}_{2}$ caps and taxes, technology incentives and prices for oil and other primary energy sources.

\section{MARKAL model expansion}

MARKAL (acronym for MARKet ALlocation) is a tool that generates bottom-up models of the energy system. It describes the energy system in terms of energy commodities and technologies. Energy supply technologies can convert primary energy to final energy and demand side technologies can convert this further to energy services. Other basic drivers for the development of the energy system are population and economic growth, expressed in demand for final energy or energy services.

The resulting model is translated into a (mixed integer) linear programming problem. MARKAL uses a mathematical solver to minimise the total discounted cost of the energy system over time within boundary conditions. Such boundary conditions may include the speed at which installed capacity can be replaced, availability of energy resources and the allowed total $\mathrm{CO}_{2}$ emissions. The relative costs of technologies and resources play an important role in determining the final mix of technologies and primary energy sources. The optimal mix may change over time as conditions change, new technologies become available and performance of existing technologies improves (e.g. through technological learning).

\subsection{The MARKAL-NL-UU model}

The MARKAL-NL-UU model describes various energy-intensive sectors of the economy in the Netherlands, like electricity and heat co-generation, and the steel and chemical industries that produce for domestic consumption and export. The model is driven by the developments of the electricity and heat demand (including heat for the residential and commercial sector from the co-generation sector) and industrial products, and was run without demand responses. ${ }^{3}$ In the model, a wide range of energy resources and technologies is represented (van den Broek et al., 2008; Smekens, 2005; Lako and Seebregts, 1998; de Feber and Gielen, 2000):

- Energy resources: coal, gas, coal, biomass, solar, wind, and nuclear.

- Energy conversion: existing conversion technologies and a diverse range of advanced technologies which could become available between 2010 and 2030 .

- $\mathrm{CO}_{2}$ capture: technologies included are post-combustion capture and pre-combustion capture of $\mathrm{CO}_{2}$ at new power

\footnotetext{
${ }^{3}$ The aim of this paper is to investigate alternative substitution of technologies and fuels to reduce GHG emissions, we did not include demand responses in the modelling. However, for similar GHG emissions reduction targets, demand is not expected to change significantly (see Proost et al., 2009; SmekensRamirez Morales, 2004; Strachan and Kannan, 2008).
}

plants, and retrofit of existing and newly built (capture-ready) power plants.

- $\mathrm{CO}_{2}$ transport and storage: infrastructure development and potential underground storage options.

We model from a country-wide public perspective using an investment discount rate of $7 \%$, not including Dutch taxes on electricity, fuels or vehicles (cf. Ministerie van Financiën, 2009) or road-pricing schemes.

\subsection{Transportation expansions}

To include the transport sector, we expand the MARKAL-NL-UU model with a comprehensive set of relevant technologies, from fuel production to end-use. Our expansion excludes transportation by air or waterways, as these transportation modes are extremely internationally oriented, are not part of existing treaties on GHG emissions reductions, and have a minority share of transportation GHG emissions (around 20\%, half of which is from shipping on the continental shelf) (Centraal Bureau voor de Statistiek, 2009b). We also exclude rail traffic and two-wheeled vehicles (motor bikes) because of their small share in transportation GHG emissions ( $<2 \%$ combined), and heavy special vehicles (agricultural and construction equipment) because of their very diverse nature. We exclude mining or conversion to intermediates of imported energy resources because these processes take place outside our model's geographical boundaries.

For end-use in the transport sector, we use kilometre demand for cars and heavy vehicles in the Netherlands. This allows our model to optimise across combinations of investment costs for vehicles and fuel production, fuel consumption, and resource cost. Instead of modelling dozens of vehicles classes, we aggregate these into the following categories:
- buses,
- cars,
- trucks, including semi-trailers, and
- vans, including very light trucks.

For cars, we assume a compact 5-seater, which is the most widely used car class in the Netherlands and includes the VW Golf, Ford Focus, Renault Megane, Toyota Corolla, and Opel Astra (Edwards et al., 2006; BOVAG-RAI, 2006). We add a variety of drivetrain technologies for cars: regular, parallel hybrid, series hybrid, plug-in hybrid, fuel cell, and battery-powered electric. For vans, we assume these are predominantly used for short distance deliveries and commercial services, in a driving pattern that is similar to cars. We add regular, parallel hybrid, series hybrid and fuel cell drivetrains for vans.

Fuel cell drivetrains are not considered a good match for long range buses and trucks due to their $2000+\mathrm{km}$ range requirement and already high efficiency of diesel drivetrains at constant speed (LBST, 2008). The same arguments extend to battery-powered electric buses and trucks. We found no real-world data for hybrid trucks, only estimates in existing studies (e.g. Fulton and Eads, 2004). We therefore use only regular diesel drivetrains for long range buses and trucks. However, we add a series hybrid bus configuration for urban public transport.

For transportation fuel supply, we add production technologies for the following synthetic fuels:

- Fischer-Tropsch (FT) diesel and petrol from gasified coal and/or biomass intermediates.

- Methanol from gasified coal and/or biomass intermediates. 
- Dimethylether (DME) from gasified coal and/or biomass intermediates.

- Hydrogen $\left(\mathrm{H}_{2}\right)$ from natural gas, gasified coal and/or biomass intermediates.

We also add import of crude oil and successive refining to diesel and petrol, as well as import of bio-ethanol from sugar cane (from e.g. Brazil) and biodiesel (from elsewhere in Europe). These default fuels and biofuels do not interact with the electricity system, nor do they offer any potential for CCS. However, they compete with synthetic fuels, hydrogen and electric driving for market share of transportation fuels.

We exclude compressed natural gas because the $\mathrm{CO}_{2}$ emissions resulting from this alternative do not differ markedly from driving on diesel and petrol 27. Bio-SNG could improve this GHG balance but its cost is higher than that of natural gas and quite similar to synthetic biofuels which are easier and cheaper to distribute. Furthermore, Bio-SNG is still in demonstration phase (Schotman, 2009). We exclude biological conversion of biomass intermediates to ethanol in NL as a separate pathway because the efficiency and cost are similar to those for methanol (Hamelinck and Faaij, 2006).

\subsection{Time and technological progress}

Technology improves over time, leading to reduced costs, higher conversion efficiencies and/or lower emissions (Berglund and Söderholm, 2006). However, technological progress is not only linked to time, but also to experience with using and producing the technology. It would be preferable to link the introduction of new technology to technological learning from global production, for example by incorporating learning curves (see Wene, 2000; de Feber et al., 2003; Junginger et al., 2005).

The Netherlands however, has a tiny market for fuel production (except for natural gas) and car sales compared to the rest of the world. All key technologies for our study will develop on a global scale, largely beyond the boundaries of our national model. As the Netherlands is not representative for the rest of the world, we do not extrapolate its production developments to the entire world, endogenous technological learning can therefore not be used in our simulations. Instead, in our data set, technologies are made available when these are projected to have passed demonstration and construction of a commercial unit, and are ready for mass production (though possibly at a price that prevents adoption). Assumptions used for technological progress in fuel conversion and car technologies are based on literature and expert judgement.

We disregard possible delays from constrained production capacity for vehicles or construction of fuel plants. In doing this we show the optimal configuration that the model arrives at, instead restraining this outcome with (somewhat arbitrary) growth constraints.

Table 1 shows the technological advances we use for fuel production and vehicle development in 5-year periods. We include only technologies that are currently in commercial or pre-commercial pilot stage, but allow for further cost reduction of these existing technologies. For this reason, no new technologies appear after 2030, and subsequent dynamics are driven entirely by scenario parameters. The timing of the appearance of new technologies is derived from roadmaps and techno-economic literature (e.g. LBST, 2008; WBCSD, 2004; IEA, 2009, 2010; van Vliet et al., 2009, in press-b, in press-a; de Wit and Faaij, 2007; Pershad and Slater, 2007). We discuss the sensitivity of our results to the timing of availability of these technologies in Section 6 .

\section{Scenario and data}

Fig. 1 shows a complete diagram of the transportation expansion of the MARKAL-NL-UU model. It presents the interaction of all energy sources, conversion technologies, fuels, and vehicles in our expansion. Tables $2 \mathrm{a}$ and $\mathrm{b}$ provide a legend, and the technologies are described further in the following sections. All energy data are expressed in lower heating value (LHV), and all monetary data is in $\epsilon_{2007}$ unless noted otherwise. Discount rate is set at $7 \%$ for investment costs. Lifespan for conversion plants describes the technical lifespan, as we do not use a business perspective. Net present values are used to determine economic lifespan.

\subsection{Transportation demand}

We use data from the Dutch statistics agency (CBS) to determine the past demand for transportation on buses, cars, trucks, and vans (Centraal Bureau voor de Statistiek, 2009c). We use other CBS data sets for the number of vehicles and total kilometres driven (Centraal Bureau voor de Statistiek, 2008, 2009d, 2009e). For future demand projections we use the Strong Europe $^{4}$ scenario, as defined in the Dutch "Welvaart en Leefomgeving" study (WLO) (Janssen et al., 2008; van Beek et al., 2008). Demand data are shown in Table 3.

For vans, the share of kilometres driven by non-diesel vehicles dropped from $9 \%$ in 2000 to $4 \%$ in 2005 . For buses and trucks, diesel vehicles made up $99 \%$ or more of the total. For simplicity, we therefore limit our investigations to diesel versions of heavy vehicles.

\subsection{Car and heavy vehicles properties}

Pursuant to Weiss et al. (2000) and JRC (Edwards et al., 2006), we use the same platform (chassis, interior, and accessories) for our regular, hybrid, electric and fuel cell car configurations, exchanging only the drivetrain. Table 4 shows the vehicle properties in our data set. Cars are assumed to have a 12 year lifespan and heavy vehicles a 15 year lifespan.

Because the modifications involved are minor (UKERC, 2008), we assume flexifuel configurations for all vehicles with an international combustion engine (ICE), enabling them to run on mixtures of fuels with comparable properties. Petrol-type fuels include regular petrol and FT petrol, which can be blended in any ratio, and bio-ethanol and methanol. We assume ethanol can be used in petrol-driven cars in blends up to $85 \%$. The required car modifications cost approximately $€ 200$ (UKERC, 2008) and are already included in vehicle prices. Diesel-type fuels include regular diesel and FT diesel, which can be blended in any ratio, and biodiesel, which can be blended up to $99 \%$. We also assume a diesel particulate filter on all new diesel-fuelled cars after 2005.

We use data for traditional cars and parallel hybrid cars from JRC (Edwards et al., 2006). Dual-fuel petrol/H2 and DME/dieseltype cars include an additional pressurised fuel tank (LPG cylinder for DME, 70 MPa cylinder for H2). Maintenance, repair and tires (MRT) costs of the five compact cars models used in our study average $41 € / 1000 \mathrm{~km}$ for petrol and $42 € / 1000 \mathrm{~km}$ for diesel versions (ANWB, 2009, van Vliet et al., in press).

For series hybrid, fuel cell and battery powered cars, we use the methodology and data set from van Vliet et al. (in press-b). Fuel consumption data for these cars has an error margin of $25 \%$.

\footnotetext{
${ }^{4}$ The Strong Europe scenario is characterised by high population growth, immigration mostly by family migrants, successful European integration, international trade coupled with environmental regulations, effective international environmental and climate policy, and solid public services.
} 
Table 1

Timeline of new technological options for fuel production and vehicles in our expanded MARKAL-NL-UU model.

\begin{tabular}{|c|c|c|c|c|c|c|c|}
\hline Vehicles & 2000 & 2005 & 2010 & 2015 & 2020 & 2025 & 2030 \\
\hline $\begin{array}{l}\text { Diesel direct } \\
\text { drivetrain }\end{array}$ & $\begin{array}{l}\text { Diesel car } \\
\text { flexifuel }\end{array}$ & & $\begin{array}{l}\text { Improved fuel } \\
\text { efficiency } \\
\text { particulate filter } \\
\text { DME option } \\
\text { parallel hybrid } \\
\text { option }\end{array}$ & & & & \\
\hline $\begin{array}{l}\text { Diesel series } \\
\text { hybrid }\end{array}$ & & & $\begin{array}{l}\text { Central motor } \\
\text { particulate filter } \\
\text { plug-in option }\end{array}$ & & $\begin{array}{l}\text { Wheel motor } \\
\text { reduced battery } \\
\text { cost }\end{array}$ & & \\
\hline $\begin{array}{c}\text { Petrol direct } \\
\text { drivetrain }\end{array}$ & $\begin{array}{l}\text { Petrol car } \\
\text { flexifuel }\end{array}$ & & $\begin{array}{l}\text { Improved fuel } \\
\text { efficiency parallel } \\
\text { hybrid option } \\
\text { hydrogen option }\end{array}$ & & & & \\
\hline $\begin{array}{l}\text { Petrol series } \\
\text { hybrid }\end{array}$ & & & $\begin{array}{l}\text { Central motor } \\
\text { plug-in option }\end{array}$ & & $\begin{array}{l}\text { Wheel motor } \\
\text { reduced battery } \\
\text { cost }\end{array}$ & & \\
\hline Electric car & & & Central motor & & $\begin{array}{l}\text { Wheel motor } \\
\text { reduced battery } \\
\text { cost }\end{array}$ & $\begin{array}{l}\text { Further reduced } \\
\text { battery cost }\end{array}$ & \\
\hline Fuel cell car & & & & & $\begin{array}{l}\text { Wheel motor } \\
\text { hydrogen option } \\
\text { petrol/diesel } \\
\text { reformer option } \\
\text { methanol/DME } \\
\text { reformer option }\end{array}$ & $\begin{array}{l}\text { Reduced fuel cell } \\
\text { cost }\end{array}$ & $\begin{array}{l}\text { Further } \\
\text { reduced fuel } \\
\text { cell cost }\end{array}$ \\
\hline Bus & Diesel bus & & & $\begin{array}{l}\text { Series hybrid } \\
\text { option }\end{array}$ & & & \\
\hline Truck & Diesel truck & & & & & & \\
\hline Van & Diesel van & & $\begin{array}{l}\text { Parallel hybrid } \\
\text { option }\end{array}$ & $\begin{array}{l}\text { Series hybrid } \\
\text { option }\end{array}$ & & & $\begin{array}{l}\text { Hydrogen fuel } \\
\text { cell option }\end{array}$ \\
\hline $\begin{array}{l}\text { Fuel } \\
\quad \text { Production }\end{array}$ & 2000 & 2005 & 2010 & 2015 & 2020 & 2025 & 2030 \\
\hline Diesel Petrol & $\begin{array}{l}\text { From crude oil in } \\
\text { refinery }\end{array}$ & & & & & & \\
\hline $\begin{array}{l}\text { FT diesel } \\
\text { FT petrol }\end{array}$ & & $\begin{array}{l}\text { From coal at } \\
\text { large scale }\end{array}$ & $\begin{array}{l}\text { From biomass at } \\
\text { medium scale }\end{array}$ & & $\begin{array}{l}\text { From biomass at } \\
\text { large scale with } \\
\text { CCS }\end{array}$ & & \\
\hline Methanol & & $\begin{array}{l}\text { From coal at } \\
\text { large scale }\end{array}$ & & & $\begin{array}{l}\text { From biomass at } \\
\text { large scale with } \\
\text { CCS }\end{array}$ & & \\
\hline DME & & & $\begin{array}{l}\text { From coal at } \\
\text { large scale }\end{array}$ & & $\begin{array}{l}\text { From biomass at } \\
\text { large scale with } \\
\text { CCS }\end{array}$ & & \\
\hline Hydrogen & $\begin{array}{l}\text { From natural gas } \\
\text { at large scale }\end{array}$ & $\begin{array}{l}\text { From coal at } \\
\text { large scale }\end{array}$ & $\begin{array}{l}\text { From natural gas } \\
\text { at small scale }\end{array}$ & & $\begin{array}{l}\text { From biomass at } \\
\text { large scale with } \\
\text { CCS }\end{array}$ & & \\
\hline Ethanol & From sugar cane & $\begin{array}{l}\text { Reduced cost } \\
\text { from sugar cane }\end{array}$ & $\begin{array}{l}\text { From cellulosic } \\
\text { biomass }\end{array}$ & $\begin{array}{l}\text { Reduced cost } \\
\text { from cellulosic } \\
\text { biomass }\end{array}$ & & & \\
\hline
\end{tabular}

For 2020, we assume the introduction of wheel motors and a cost reduction for batteries from $1000-1600 € / \mathrm{kWh}$ in 2010 to $800 € /$ $\mathrm{kWh}$. For electric cars we assume a minimum range of $250 \mathrm{~km}$ and a further reduction of battery costs to $400 € / \mathrm{kWh}$ in 2025 .

Direct hydrogen fuel cells are around 55\% efficient (Edwards et al., 2006). We assume a cost reduction for fuel cell packs from $1200 € / \mathrm{kWe}$ in 2020 to $660 € / \mathrm{kWe}$ in 2025 and $110 € / \mathrm{kWe}$ in 2030. Fuel cell cars can also be equipped with a reformer that converts any diesel-type or petrol-type fuels to hydrogen, or converts methanol or DME to hydrogen. Including reformer losses, fuel cells are assumed to be around $38 \%$ efficient on diesel/petrol and around $42 \%$ on methanol/DME. Reformer cost is set at $150 € / \mathrm{kWe}$ (Edwards et al., 2006).
For buses, we assume a large bus like the Mercedes Citaro or Berkhof Ambassador. We use the certified fuel consumption data published by Mercedes-Benz and e-Traction for regular diesel buses and series hybrid buses in an urban setting (Mercedes-Benz Omnibusse, 2008; e-Traction, 2009).

For regular trucks and diesel vans, we use average fuel consumption and emission factors applied by the Dutch statistics agency (Centraal Bureau voor de Statistiek, 2009c, 2009d). We aggregate semi-trailers with trucks because emissions are similar (Centraal Bureau voor de Statistiek, 2009c). We assume that driving patterns are similar as well.

For vans, we consider regular ICE, parallel hybrid, series hybrid and fuel cell configurations. We assume the same relative fuel 

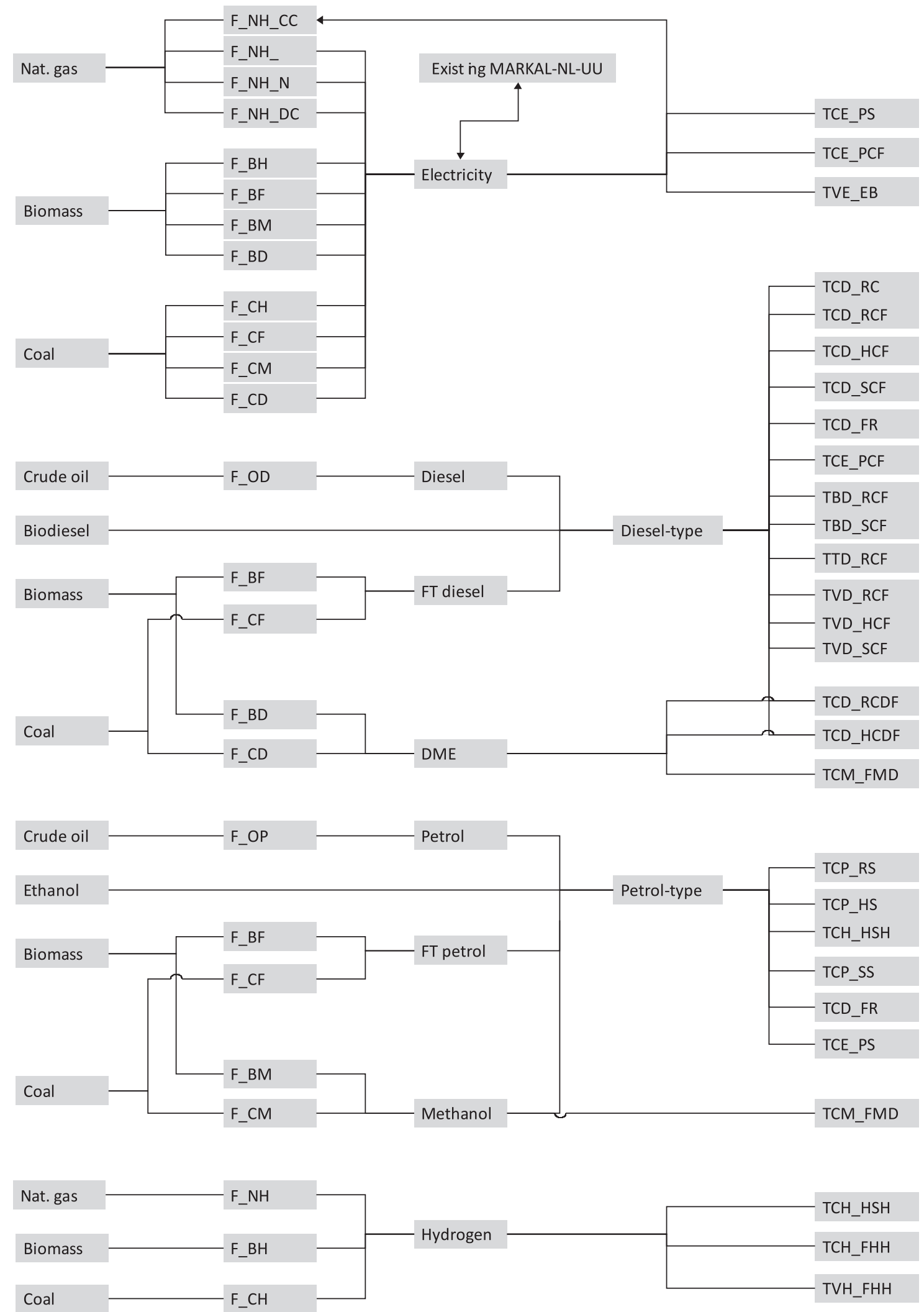

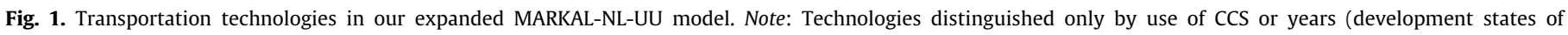
technology) are bundled if connections are identical.

consumption benefits for hybridisation and fuel cells as for hybrid (18\% reduction for parallel, $34 \%$ for series) and fuel cell cars $(61 \%$ using hydrogen). We use an average of the purchase cost of five state-of-the-art diesel vans, assuming an engine close to $90 \mathrm{~kW}$. As with cars, we only vary the drivetrain to determining purchase cost of hybrid vans. For parallel hybrid vans, a $17 \mathrm{~kW}$ motor and 
Table 2a

Legend for fuel conversion technologies in Fig. 1.

\begin{tabular}{|c|c|c|c|}
\hline Technology family & Feedstock & Main product & Extras \\
\hline F: fuel & $\begin{array}{l}\mathrm{N} \text { : natural gas } \\
\mathrm{B} \text { : biomass } \\
\mathrm{C} \text { : coal } \\
\mathrm{O} \text { : crude oil (refinery) }\end{array}$ & $\begin{array}{l}\text { H: hydrogen } \\
\text { F: Fischer-Tropsch } \\
\text { M: methanol } \\
\text { D: DME } \\
\text { P: petrol } \\
\text { D: diesel }\end{array}$ & $\begin{array}{l}\text { CC: centralised with capture } \\
\text { DC: decentralised with capture } \\
\mathrm{N} \text { : decentralised without capture }\end{array}$ \\
\hline
\end{tabular}

No extra indicates the conversion plant is a large, centralised facility that is not equipped to provide transport-ready captured $\mathrm{CO}_{2}$.

Table 2b

Legend for vehicle technologies in Fig. 1.

\begin{tabular}{|c|c|c|c|c|c|}
\hline Technology family & & Primary fuel & Drivetrain & Powerplant & Extras \\
\hline \multirow[t]{6}{*}{$\mathrm{T}$ : transportation } & C: car & D: diesel-type & $\mathrm{R}$ : regular drivetrain & C: compression engine & F: particulate filter \\
\hline & B: bus & P: petrol-type & $\mathrm{H}$ : parallel hybrid & S: spark ignition engine & D: extra DME tank \\
\hline & $\mathrm{T}$ : truck & $\mathrm{H}$ : hydrogen & S: series hybrid & B: battery only & $\mathrm{H}$ : (extra) hydrogen tank \\
\hline & V: van & E: electric & P: plug-in hybrid & $\mathrm{H}$ : hydrogen fuel cell & \\
\hline & & M methanol & F: fuel cell & M: methanol reformer & \\
\hline & & & E: full electric & $\mathrm{R}$ : diesel/petrol reformer & \\
\hline
\end{tabular}

Table 3

Distance driven and number of vehicles on the road from 2005 to 2040

\begin{tabular}{lcccccc}
\hline Transport demand & 2000 & 2005 & 2010 & 2020 & 2030 & $2040^{\mathrm{a}}$ \\
\hline Total distance & $\left(10^{9} \mathrm{~km} /\right.$ year $)$ & & & & & \\
Cars & 91 & 97 & 107 & 124 & 134 & 144 \\
Diesel & 23 & 29 & tbd & tbd & tbd & tbd \\
Petrol & 68 & 68 & tbd & tbd & tbd & tbd \\
Buses & 0.6 & 0.6 & 0.7 & 0.6 & 0.7 & 0.7 \\
Trucks & 6.8 & 6.8 & 8.0 & 9.0 & 9.7 & 10.3 \\
Vans & 15 & 18 & 20 & 20 & 23 & 27
\end{tabular}

$\begin{array}{lllllll}\text { Average distance per vehicle }\left(10^{3}\right. & \mathrm{km} / \text { vehicle/year }) \\ \text { Cars } & 14 & 14 & 14 & 14 & 14 & 14 \\ \text { Buses } & 58 & 57 & 57 & 57 & 57 & 57 \\ \text { Trucks } & 48 & 48 & 47 & 47 & 47 & 47 \\ \text { Vans } & 22 & 20 & 21 & 21 & 21 & 21\end{array}$

$\begin{array}{lcrllll}\text { Number of vehicles }\left(10^{3} \text { vehicles }\right) & & & & & \\ \text { Cars } & 6343 & 6992 & 7607 & 8777 & 9504 & 10,443 \\ \text { diesel } & 798 & 1069 & \text { tbd } & \text { tbd } & \text { tbd } & \text { tbd } \\ \text { petrol } & 5545 & 5922 & \text { tbd } & \text { tbd } & \text { tbd } & \text { tbd } \\ \text { Buses } & 11 & 11 & 12 & 11 & 11 & 12 \\ \text { Trucks } & 140 & 142 & 171 & 193 & 206 & 219 \\ \text { Vans } & 696 & 893 & 945 & 950 & 1101 & 1252\end{array}$

$\mathrm{CO}_{2}$ emissions $\left(10^{6} \mathrm{~kg} /\right.$ year $)$

$\begin{array}{lrrllll}\text { Cars } & 17,338 & 18,234 & \text { tbd } & \text { tbd } & \text { tbd } & \text { tbd } \\ \text { Buses } & 576 & 572 & \text { tbd } & \text { tbd } & \text { tbd } & \text { tbd } \\ \text { Trucks } & 6079 & 6179 & \text { tbd } & \text { tbd } & \text { tbd } & \text { tbd } \\ \text { Vans } & 3819 & 4662 & \text { tbd } & \text { tbd } & \text { tbd } & \text { tbd }\end{array}$

Note: Based on the Strong Europe scenario (van Beek et al., 2008). $\mathrm{CO}_{2}$ emissions from the Dutch National Statistics Agency (CBS, Centraal Bureau voor de Statistiek, 2009c).

a WLO projects transportation growth of $30 \%$ of passenger $\mathrm{km}$ and $40 \%$ of freight km by 2040 vs. 2002. Extrapolations arrived at a $42 \%$ growth in passenger $\mathrm{km}$ and $39.4 \%$ growth in freight $\mathrm{km}$ by 2030 . With cars on the road projected to rise to 9.7 million, we reconcile by assuming a $2 \%$ decline in average distance per car. tbd: to be determined.

$7 \mathrm{kWh}$ battery are added. For series hybrids or fuel cell vans, the engine is replaced by a $90 \mathrm{~kW}$ motor, and a $74 \mathrm{~kW}$ generator or direct hydrogen fuel cell stack.

\subsection{Production and distribution of synthetic fuels}

We use the methodology and data set from van Vliet et al. (2009) to construct 19 configurations of centralised conversion plants. These include five plant configurations that produce Fischer-Tropsch (FT) synthetic diesel and petrol from coal (coal-to-liquids or CTL) or biomass intermediates (BTL). The B_FT_10 plant is dimensioned at $400 \mathrm{MW}_{\text {th }}$ and the other 18 configurations of centralised plants are dimensioned at $2 \mathrm{GW}_{\mathrm{th}}$. Based on the same methodology and data, we added six plant configurations that produce hydrogen from coal, biomass intermediates or natural gas, with or without CCS. Based on additional data from Hamelinck and Faaij (2002) and Larson et al. (2005), we add four plant configurations that produce methanol and four that produce DME. The synthetic fuel plants co-produce electricity and also intrinsically provide a low-cost stream of pure $\mathrm{CO}_{2}$ that is readily transported off-site and stored (CCS) (van Vliet et al., 2009).

We also include two small scale (2 MW) on-site natural gas reformer configurations, using data from Sjardin et al. (2006), and two oil refining technologies as described in van Vliet et al. (2009). Table 5 shows the conversion plant configurations used in this study. Electricity produced or consumed, and $\mathrm{CO}_{2}$ sent to underground storage are integrated into the existing MARKAL-NL-UU model system. Applying CCS reduces the net output of electricity because electricity is needed to compress the $\mathrm{CO}_{2}$ for transport.

The plants are expected to have a 35 year lifespan, and to be available $8000 \mathrm{~h} /$ year (91\% of time). Instead of gradually reducing the cost of the synthetic fuel conversion technologies over time, we introduce sets of more advanced conversion technologies, to reflect that fuel conversion plants are part of larger logistical chains which must be introduced interdependently. For example, upstream conversion of biomass to an intermediate must be coupled with to downstream conversion of that intermediate to FT fuel.

For distribution of liquid fuels, we use the same costs and energy consumption as for diesel and petrol (cf. Edwards et al., 2006). We encountered costs for distribution of petrol and diesel between $1.37 € / G J$ (Iowa Department of Transportation, 2009; EIA, 2009a) and around $1.70 € / G J$ (EIA, 2009b), and we settle on $1.50 € / G J$ excluding VAT (also used in Hamelinck and Faaij, 2002 quoting Ogden et al., 1999). Energy consumed in distribution is $0.0034 \mathrm{GJ}_{\mathrm{e}} / \mathrm{GJ}_{\text {fuel }}$ and $0.0132 \mathrm{GJ}_{\text {diesel }} / \mathrm{GJ}_{\text {fuel }}$ (Edwards et al., 2006). 
Table 4

Costs, fuel consumption and emissions of vehicle technologies used in our model.

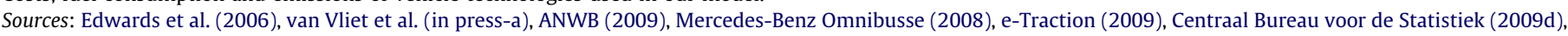
Centraal Bureau voor de Statistiek ( 2009c).

\begin{tabular}{|c|c|c|c|c|c|}
\hline Designation & Characteristics & Available from year & $\begin{array}{l}\text { Purchase and VAT } \\
\text { (k€/vehicle) }\end{array}$ & $\begin{array}{l}\text { Fuel consumption and emissions } \\
\text { (fuel: } \mathrm{km} \text { driven } / \mathrm{GJ}_{\text {fuel }} \text { ) }\end{array}$ & \\
\hline \multicolumn{6}{|l|}{ Regular cars } \\
\hline TCP_RS_02 & Regular petrol car & 2002 & 20 & Petrol-type: 447 & \\
\hline TCP_RS_10 & Regular petrol car & 2010 & 21 & Petrol-type: 526 & \\
\hline TCD_RC_02 & Regular diesel car & 2002 & 22 & Diesel-type: 546 & \\
\hline TCD_RCF_10 & with particulate filter (DPF) & 2010 & 23 & Diesel-type: 566 & \\
\hline TCD_RCDF10 & with DME tank and DPF & 2010 & 24 & Diesel-type: 566 & DME: 566 \\
\hline \multicolumn{6}{|l|}{ Hybrid cars } \\
\hline TCD_HCF_10 & Parallel hybrid & 2010 & 29 & Diesel-type: 687 & \\
\hline TCD_HCDF10 & Parallel hybrid with DME tank & 2010 & 30 & Diesel-type: 687 & DME: 687 \\
\hline TCP_HS_10 & Parallel hybrid & 2010 & 26 & Petrol-type: 663 & \\
\hline TCH_HSH_10 & Parallel hybrid with hydrogen & 2010 & 32 & $\mathrm{H} 2 \mathrm{cg}: 673$ & petrol-type: 606 \\
\hline TCD_SCF_10 & Series hybrid: central motor & 2010 & 28 & Diesel-type: 862 & \\
\hline TCD_SCF_20 & Series hybrid: wheel motor & 2020 & 25 & Diesel-type: 997 & \\
\hline TCP_SS_10 & Series hybrid: central motor & 2010 & 26 & Petrol-type: 801 & \\
\hline TCP_SS_20 & Series hybrid: wheel motor & 2020 & 23 & Petrol-type: 927 & \\
\hline \multicolumn{6}{|l|}{ Fuel cell cars } \\
\hline TCM_FMD_20 & Fuel cell and methanol/DME & 2020 & 86 & Methanol: 1269 & DME: 1269 \\
\hline TCM_FMD_25 & Fuel cell and methanol/DME & 2025 & 59 & Methanol: 1269 & DME: 1269 \\
\hline TCM_FMD_30 & Fuel cell and methanol/DME & 2030 & 33 & Methanol: 1269 & DME: 1269 \\
\hline TCD_FR_20 & Fuel cell and diesel/petrol & 2020 & 86 & Diesel-type: 1148 & petrol-type: 1148 \\
\hline TCD_FR_25 & Fuel cell and diesel/petrol & 2025 & 59 & Diesel-type: 1148 & petrol-type: 1148 \\
\hline TCD_FR_30 & Fuel cell and diesel/petrol & 2030 & 33 & Diesel-type: 1148 & petrol-type: 1148 \\
\hline TCH_FHH_20 & Fuel cell and hydrogen tank & 2020 & 81 & H2 cg: 1662 & \\
\hline TCH_FHH_25 & Fuel cell and hydrogen tank & 2025 & 54 & H2 cg: 1662 & \\
\hline TCH_FHH_30 & Fuel cell and hydrogen tank & 2030 & 28 & H2 cg: 1662 & \\
\hline \multicolumn{6}{|c|}{ Plug-in hybrid and electric cars } \\
\hline TCE_PS_10 & Plug-in hybrid (50 km electric) & 2010 & 32 & Electricity: 2325 & petrol-type: 801 \\
\hline TCE_PS_20 & Plug-in hybrid (50 km electric) & 2020 & 28 & Electricity: 2692 & petrol-type: 927 \\
\hline TCE_PCF_10 & Plug-in hybrid (50 km electric) & 2010 & 34 & Electricity: 2325 & diesel-type: 862 \\
\hline TCE_PCF_20 & Plug-in hybrid (50 km electric) & 2020 & 30 & Electricity: 2692 & diesel-type: 997 \\
\hline TCE_EB_10 & Full electric $(250 \mathrm{~km})$ & 2010 & 59 & Electricity: 2325 & \\
\hline TCE_EB_20 & Full electric ( $250 \mathrm{~km})$ & 2020 & 47 & Electricity: 2692 & \\
\hline TCE_EB_25 & Full electric (250 km) & 2025 & 33 & Electricity: 2692 & \\
\hline \multicolumn{6}{|l|}{ Buses } \\
\hline TBD_RCF_00 & Regular diesel bus & 2000 & 196 & Diesel-type: 70 & \\
\hline TBD_SCF_15 & Series hybrid: wheel motor & 2015 & 235 & Diesel-type: 183 & \\
\hline \multicolumn{6}{|l|}{ Truck } \\
\hline TTD_RCF_00 & Regular diesel truck & 2000 & $\mathrm{n} / \mathrm{a}$ & Diesel-type: 80 & \\
\hline \multicolumn{6}{|l|}{ Vans } \\
\hline TVD_RCF_00 & Regular diesel van & 2000 & 22 & Diesel-type: 284 & \\
\hline TVD_HCF_10 & Parallel hybrid diesel van & 2010 & 29 & Diesel-type: 344 & \\
\hline TVD_SCF_15 & Series hybrid: central motor & 2015 & 29 & Diesel-type: 432 & \\
\hline TVH_FHH_30 & Fuel cell and hydrogen tank & 2020 & 35 & $\mathrm{H} 2 \mathrm{cg}: 720$ & \\
\hline
\end{tabular}

Note: Truck purchasing cost varies widely and is not required because only one baseline diesel option is used.

For distribution of DME, we use the same costs and energy consumption of $0.01 \mathrm{GJ}_{\mathrm{e}} / \mathrm{GJ}_{\text {fuel }}$ and $0.02 \mathrm{GJ}_{\text {diesel }} / \mathrm{GJ}_{\text {fuel }}$.

For distribution of hydrogen we use a cost of $3.2 € / G J$ for transport by pipeline and $3.4 € / G \mathrm{~J}$ for dispensing at the fuel station (Damen et al., 2007; de Wit and Faaij, 2007). Energy consumed in dispensing of $\mathrm{H}_{2}$ (mostly for compression to $70 \mathrm{MPa}$ ) is set at $0.07 \mathrm{GJ}_{\mathrm{e}} / \mathrm{GJ}_{\mathrm{H}_{2}}$ (Edwards et al., 2006).

\subsection{Supply of energy resources}

We use prices of fossil energy resources as described in the WEO 2009 from 2015 to 2030 (IEA, 2009), and keep prices constant after 2030. We use the $450 \mathrm{ppm}$ WEO 2009 scenario data unless noted otherwise because stringent $\mathrm{CO}_{2}$ restrictions (in any form) are likely to reduce demand for fossil energy sources and cause lower prices
(Strachan and Kannan, 2008). For 2010, we use a coal price of $1.8 € /$ GJ, a natural gas price of $5.1 € / G J$, and an oil price of $80 \$ / \mathrm{bbl}$.

We also include direct emissions from burning energy resources and indirect GHG emissions for extraction, processing and transportation (Edwards et al., 2006). Indirect emissions from possible land-use change are outside the scope of this study and are not included. We assume that biomass feedstock is produced meeting relevant criteria for sustainability (see EU, 2009; Cramer and Duurzame productie van biomassa, 2006). Table 6 summarises the emission factors and energy resource prices used in this study.

At $80 \$ / \mathrm{bbl}^{5}$ fuel prices at the pump in the Netherlands are around $1.18 € / 1$ for diesel and $1.37 € / 1$ for petrol (using Shell Nederland, 2008).

\footnotetext{
${ }^{5}$ We assume $41.87 \mathrm{MJ} / \mathrm{kg}$ and $820 \mathrm{~kg} / \mathrm{m}^{3}$ for crude oil (Edwards et al., 2006), and average exchange rates of US\$/€ of 0.80 in 2005 and 2006, 0.73 in 2007, 0.68 in 2008 and 0.72 in 2009 (oanda.com, 2007).
} 
Table 5

Inputs, outputs, costs, and emissions of conversion technologies used in our model.

Sources: van Vliet et al. (2009), Sjardin et al. (2006), and additional data from Hamelinck and Faaij (2002), and Larson et al. (2005).

\begin{tabular}{|c|c|c|c|c|c|c|c|}
\hline \multirow[t]{2}{*}{ Designation } & \multirow[t]{2}{*}{ Feedstock } & \multirow[t]{2}{*}{ Outputs (fuel: $\mathrm{GJ}_{\mathrm{out}} / \mathrm{GJ}_{\mathrm{in}}$ ) } & \multirow{2}{*}{$\begin{array}{l}\text { Investment } \\
\left(€ / \mathrm{kW}_{\mathrm{in}}\right)\end{array}$} & \multirow{2}{*}{$\begin{array}{l}\text { O\&M } \\
\left(€ / \mathrm{kW}_{\text {in }} / \mathrm{yr}\right)\end{array}$} & \multirow{2}{*}{$\begin{array}{l}\text { Variable } \\
\left(€ / G J_{\text {in }}\right)\end{array}$} & \multicolumn{2}{|c|}{ Emissions $\left(\mathrm{kg} \mathrm{CO} / \mathrm{CJ}_{\mathrm{in}}\right)$} \\
\hline & & & & & & to air & to $\mathrm{CCS}$ \\
\hline \multicolumn{8}{|c|}{ Fischer-Tropsch } \\
\hline F_CF_05 & Bituminous coal & FT diesel: 0.438 , electricity: 0.072 , FT petrol: 0.078 & 668 & 30 & & 56 & 0 \\
\hline F_CF_20_CC & Bituminous coal & FT diesel: 0.438 , electricity: 0.054 , FT petrol: 0.078 & 685 & 30 & & 7 & 49 \\
\hline F_BF_10 & Biomass intermed. & FT diesel: 0.429 , electricity: 0.064 , FT petrol: 0.076 & 933 & 40 & & 69 & 0 \\
\hline F_BF_20 & Biomass intermed. & FT diesel: 0.425 , electricity: 0.091 , FT petrol: 0.076 & 646 & 29 & & 55 & 0 \\
\hline F_BF_20_CC & Biomass intermed. & FT diesel: 0.425 , electricity: 0.074 , FT petrol: 0.076 & 662 & 29 & & 7 & 48 \\
\hline \multicolumn{8}{|l|}{ Hydrogen } \\
\hline F_CH_05 & Bituminous coal & H2: 0.705 , electricity: 0.036 & 550 & 25 & & 92 & 0 \\
\hline F_CH_20_CC & Bituminous coal & H2: 0.705 , electricity: 0.004 & 579 & 26 & & 1 & 91 \\
\hline F_BH_20 & Biomass intermed. & H2: 0.683 , electricity: 0.048 & 600 & 27 & & 90 & 0 \\
\hline F_BH_20_CC & Biomass intermed. & H2: 0.683 , electricity: 0.017 & 628 & 28 & & 1 & 89 \\
\hline F_NH_OO & Natural gas & H2: 0.7 , electricity: 0.037 & 452 & 21 & & 53 & 0 \\
\hline F_NH_20_CC & Natural gas & H2: 0.7 , electricity: 0.019 & 472 & 21 & & 2 & 51 \\
\hline F_NH_10_N & Natural gas & $\mathrm{H} 2: 0.737,: 0$ & 554 & 362 & & 56 & 0 \\
\hline F_NH_10_DC & Natural gas & $\mathrm{H} 2: 0.728,: 0$ & 620 & 378 & & 25 & 33 \\
\hline \multicolumn{8}{|l|}{ Methanol } \\
\hline F_CM_05 & Bituminous coal & methanol: 0.558 , electricity: 0.063 & 600 & 27 & & 54 & 0 \\
\hline F_CM_20_CC & Bituminous coal & methanol: 0.558 , electricity: 0.046 & 617 & 27 & & 7 & 47 \\
\hline F_BM_20 & Biomass intermed. & methanol: 0.54 , electricity: 0.092 & 546 & 22 & & 53 & 0 \\
\hline F_BM_20_CC & Biomass intermed. & methanol: 0.54 , electricity: 0.076 & 546 & 22 & & 7 & 46 \\
\hline \multicolumn{8}{|l|}{$D M E$} \\
\hline F_CD_10 & Bituminous coal & DME: 0.572 , electricity: 0.072 & 606 & 27 & & 54 & 0 \\
\hline F_CD_20_CC & Bituminous coal & DME: 0.572 , electricity: 0.054 & 642 & 28 & & 7 & 47 \\
\hline F_BD_20 & Biomass intermed. & DME: 0.554 , electricity: 0.095 & 560 & 23 & & 53 & 0 \\
\hline F_BD_20_CC & Biomass intermed. & DME: 0.554 , electricity: 0.077 & 570 & 23 & & 7 & 46 \\
\hline \multicolumn{8}{|l|}{ Oil refining } \\
\hline F_OP_00 & Crude oil & petrol: 0.914 & & & 2.6 & 7 & 0 \\
\hline F_OD_00 & Crude oil & diesel: 0.897 & & & 2.6 & 8 & 0 \\
\hline
\end{tabular}

Table 6

Energy resource GHG emissions and prices used in our model.

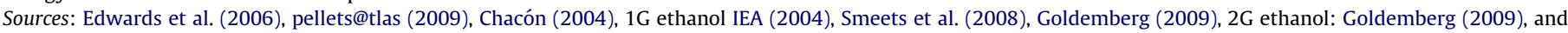
Hamelinck et al. (2005).

\begin{tabular}{|c|c|c|c|c|c|c|c|c|c|}
\hline \multirow[t]{2}{*}{ Energy resource } & & \multicolumn{2}{|c|}{ Emissions $\left(\mathrm{kg} \mathrm{CO} \mathrm{CO}_{2 \mathrm{eq}} / \mathrm{GJ}\right)$} & \multicolumn{6}{|c|}{ Price $(€ / G J)$} \\
\hline & & Direct $^{\mathrm{a}}$ & Indirect & 2000 & 2005 & 2010 & 2020 & 2030 & 2040 \\
\hline Biodiesel & & & 29 & 22 & 22 & 22 & 22 & 22 & 22 \\
\hline Biomass intermediates & & & 5 & 7.2 & 7.0 & 6.8 & 6.8 & 6.8 & 6.8 \\
\hline \multirow[t]{2}{*}{ Coal } & Reference & 93 & 15 & 1.1 & 1.8 & 1.9 & 2.4 & 2.5 & 2.5 \\
\hline & $450 \mathrm{ppm}$ & 93 & 15 & 1.1 & 1.8 & 1.9 & 1.8 & 1.5 & 1.5 \\
\hline Crude oil & & 76 & 3 & 4.9 & 7.9 & 9.8 & 11.0 & 11.0 & 11.0 \\
\hline \multirow[t]{2}{*}{ Ethanol } & Sugar cane & 22 & 22.3 & 18.4 & 13.0 & 13.0 & 13.0 & 13.0 & \\
\hline & Cellulosic & & 22 & & & 25.6 & 13.3 & 13.3 & 13.3 \\
\hline Natural gas & & 56 & 12 & 2.6 & 4.7 & 5.4 & 7.0 & 7.0 & 7.0 \\
\hline
\end{tabular}

a Bio-based fuels are assumed to be carbon-neutral except for inputs in processing and transport.

This is equivalent to untaxed prices of $17.4 € / G$ J for diesel and $18.0 € /$ GJ for petrol at the refinery gate. Petrol and diesel prices include refining and a profit margin for producers but not distribution and marketing.

Conversion costs, efficiency and emissions of refineries used in this study are shown in Table 5 . We limit the ratio between diesel and petrol production, because refineries are bound by crude oil composition and installed processing facilities. Existing production of road transportation fuel by refineries in the Netherlands shifted from 51\% diesel in 2000 to $63 \%$ diesel in 2008 (Centraal Bureau voor de Statistiek, 2009a). We assume a maximum further $20 \%$ adjustment, limiting diesel to between $40 \%$ and $76 \%$ of refinery fuel product from crude oil.

\subsection{Supply of biodiesel, ethanol, and lignocellulosic biomass}

For biodiesel, we assume imports of a fatty acid methyl ester (FAME), produced either from rapeseed (as by-product for animal feed) or sunflower. Production in 2008 in the EU-27 was estimated at $331 \mathrm{PJ}$, and consumption in the Netherlands at 8.5 PJ (EurObserv'ER, 2009). We use a conservative median production cost from the EU-15 of approximately $22 € / G J$ biodiesel (Chacón, 2004; cf. de Wit and Faaij, 2008). Feasible production is capped at $300 \mathrm{PJ} /$ year for the EU (Edwards et al., 2006; Chacón, 2004), of which $3.2 \%$ or $9.6 \mathrm{PJ} /$ year is allocated to the Netherlands on the basis of EU population share. We assume no imports of biodiesel from outside the EU. 
Table 7

Biomass availability in our model (PJ/year).

Sources: Dornburg et al. (2010), Hoefnagels et al. (2009), EurObserv’ER (2006), Edwards et al. (2006), and Chacón (2004).

\begin{tabular}{|c|c|c|c|c|c|}
\hline Biomass availability (PJ/year) & 2005 & 2010 & 2020 & 2030 & 2040 \\
\hline Global generic biomass & 9000 & 27,000 & 66,000 & 114,000 & 181,000 \\
\hline Allocated to the Netherlands & & 122 & 299 & 517 & 823 \\
\hline Allocation to Dutch power and biofuel production & (Consumed) 63 & 104 & 256 & 443 & 705 \\
\hline Biodiesel in Europe & (Produced) 133 & 300 & 300 & 300 & 300 \\
\hline Biodiesel allocated to the Netherlands & (Consumed) 0 & 10 & 10 & 10 & 10 \\
\hline
\end{tabular}

For ethanol, we assume imports from Brazil, currently the largest producer of bio-ethanol. In addition, we base ethanol cost on the fermentation of sugar cane that is produced in a fair and equitable way. Fair production is assumed to costs $37 \%$ or $5 € / G J$ more than the cheapest current production method (Smeets et al., 2008) and uses 1.9 GJ biomass (cane)/GJethanol (Macedo, 2008, Edwards et al., 2006). For cellulosic (2nd generation) ethanol, we assume the same cost increase for sustainable production, but using $1.3 \mathrm{GJ}_{\text {biomass }} / \mathrm{GJ}_{\text {ethanol }}$ (Macedo, 2008, Hamelinck et al., 2005).

To be conservative, we maintain current ethanol production costs for prices (Goldemberg, 2009; van den Wall-Bake et al., 2009; IEA, 2004). Cost reductions seem to have slowed (Goldemberg, 2009) while at the same time showing potential to decrease by a further $30 \%$ by 2020 (van den Wall-Bake et al., 2009). We assume that higher future oil prices would allow producers to produce more sustainably and/or raise profit margins while keeping ethanol competitive with other fuels.

For biomass pellets, we assume either compressed wood pellets or torrified and compressed wood pellets (TOPs). These can be used to (co-)fire electricity plants or converted to transportation fuels. Processing consumes $7-18 \%$ of raw biomass energy (van Vliet et al., 2009; Uslu et al., 2008), for an average of $1.13 \mathrm{GJ} / \mathrm{GJ}$ biomass intermediate. For prices of biomass intermediates, we use a price of $7 € / G J$ in 2005 (derived from pellets@tlas, 2009; Ragwitz et al., 2009). This price allows cost margin for sustainable production of raw biomass (cf. Smeets et al., 2010). We assume this price to be constant for most of our scenario variants, but also tested the impact of prices rising to $10.5 € / G J$ in 2050 and prices falling to production costs of approximately $4 € / \mathrm{GJ}$ (van Vliet et al., 2009).

Table 6 shows biomass resource prices and Table 7 shows the available biomass and biodiesel used in our study.

Based on the global biomass potential assessment study (Dornburg et al., 2010), $290 \mathrm{EJ}$ is assumed to be available around in 2050. This represents an intermediate level biomass potential with medium yield improvements in agricultural technology, while excluding protected and degraded areas. We based the growth of biomass potential on the average of a development with linear growth and one with a growth rate of $8 \% / y e a r$, so that the global biomass available for modern bioenergy use increases from 9 EJ in $2005^{6}$ to 290 EJ in 2050.

We allocate part of this global biomass potential to the Netherlands by the average of two principles: the egalitarian fairness principle (i.e. equal biomass supply per capita) and the sovereignty principle (i.e. current share of national energy use in global energy use). Of the biomass available for Dutch consumption, we allocate $86 \%$ to the transport and power sectors (Hoefnagels et al., 2009).

\footnotetext{
${ }^{6}$ In addition, around $39 \mathrm{EJ}$ of traditional biomass (charcoal, wood, and manure for cooking and space heating) was used (Johansson and Goldemberg, 2004).
}

\subsection{Electricity generation sector}

In MARKAL-NL-UU, a large number of electricity generation technologies are implemented, including power plants with CCS, nuclear power plants, and renewable electricity generation technologies. The large scale power plants operated in this model are either natural gas combined cycle power plants (NGCC), pulverised coal-fired power plants with possible co-firing of biomass (PC), integrated coal (and biomass) gasification power plants (IGCC), or gas-fired combined heat and power generation plants (CHP).

Cost and performance data for the electricity generation technologies in MARKAL-NL-UU come from a wide variety of sources and are enumerated in van den Broek et al. (2008, in press). We assume that IGCC and NGCC power plants have a lifespan of 40 years, PCs 50 years, and large scale CHP units 30 years.

In this study, we assume that the Dutch electricity demand will increase from 110 TWh in 2005 to 175 TWh in 2050. This is in line with the electricity demand growth in the Strong Europe scenario used by the Dutch planning agencies (Farla et al., 2008).

Three other assumptions concern the deployment of a few specific power plant types and export of electricity. First, in MARKAL-NL-UU, a bound is set to phase out 450MW of existing nuclear power in 2033 (VROM, 2006). Secondly, three planned pulverised coal-fired power plants with a total capacity of $3.4 \mathrm{GW}$ are built before 2015. Thirdly, instead of importing electricity (i.e. 18 TWh in 2005) electricity may be exported from 2010 to 2020. From 2020, no electricity export is allowed in the model in order to keep the analysis focussed on the Dutch electricity market.

Regarding electric vehicles, the timing of recharging such vehicles may influence the required capacity of electricity generation and the distribution grid. In the MARKAL-NL-UU model, electricity production is divided into six intervals: day, evening and night, for summer and for winter. We assume that $50 \%$ of recharging takes place at night (between 23:00 and 7:00), and $50 \%$ during the rest of the day, irrespective of the season.

\section{7. $\mathrm{CO}_{2}$ capture, transport, and storage}

In the MARKAL-NL-UU model, $\mathrm{CO}_{2}$ capture units are implemented for industrial processes generating medium-sized quantities of pure $\mathrm{CO}_{2}$ (e.g. hydrogen, ammonia, or ethylene oxide production units) or large quantities at a single site (e.g. steel industry, refineries, or ethylene production units). Cost and performance data of these units are described in Damen et al. (2009).

The $\mathrm{CO}_{2}$ storage reservoir inventory in our model is based on data compiled by Christensen and Holloway (2004), Kramers et al. (2007). TNO (2007c, 2007b), and Ramírez et al. (2009). It results in a selection of $123 \mathrm{CO}_{2}$ hydrocarbon fields and aquifers which are considered suitable for $\mathrm{CO}_{2}$ storage (e.g. deeper than $800 \mathrm{~m}$, reservoir rocks with porosity more than $10 \%$ ) with a total 
Table 8

$\mathrm{CO}_{2}$ transport and storage costs used in our model.

\begin{tabular}{|c|c|c|c|c|}
\hline $\mathrm{CO}_{2}$ transport and storage & $\begin{array}{l}\text { investment } \\
(\mathrm{M} € \text { per } \mathrm{Mt} / \mathrm{yr} \text { ) }\end{array}$ & $\begin{array}{l}\text { Fixed o\&M } \\
(M € \text { per } M t / y r)\end{array}$ & $\begin{array}{l}\text { Life time } \\
\text { (years) }\end{array}$ & $\begin{array}{l}\mathrm{CO}_{2} \text { storage } \\
\text { capacity }(\mathrm{Gt})\end{array}$ \\
\hline \multicolumn{5}{|l|}{ Transport $^{\mathrm{a}}$} \\
\hline To fields offshore & 31 & 0.9 & 40 & \\
\hline To fields onshore & 20 & 0.6 & 40 & \\
\hline To the Norwegian Utsira field & 42 & 1.5 & 40 & \\
\hline \multicolumn{5}{|l|}{ Storage } \\
\hline Aquifers offshore & 196 & 9.6 & 21 & 0.0 \\
\hline Aquifers onshore & 83 & 3.8 & 28 & 0.0 \\
\hline Depleted gas fields offshore & 32 & 1.4 & 19 & 1.0 \\
\hline Depleted gas fields offshore without re-use & 111 & 5.3 & 19 & \\
\hline Depleted gas fields onshore & 11 & 0.4 & 22 & 1.2 \\
\hline Depleted gas fields onshore without re-use & 23 & 1.0 & 22 & \\
\hline Norway, Utsira field, offshore & 18 & 0.9 & 25 & 42 \\
\hline
\end{tabular}

a van den Broek et al. (in press) modelled each pipeline separately. $\mathrm{CO}_{2}$ transport costs were assumed to be proportional to meter length and per meter diameter of the

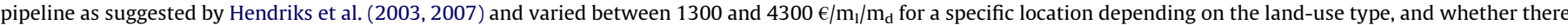

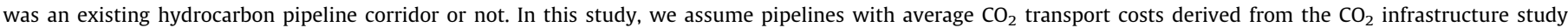
(van den Broek et al., in press).

${ }^{\mathrm{b}}$ Unit cost estimates of setting up and maintaining $\mathrm{CO}_{2}$ storage facilities (e.g. costs for site exploration and development, an offshore platform, drilling costs per meter)

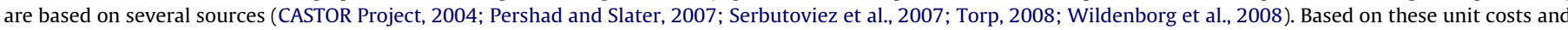
the characteristics of the individual sinks (e.g. depth, location), we estimate average costs for the different $\mathrm{CO}_{2}$ storage categories.

estimated $\mathrm{CO}_{2}$ storage capacity of $1.2 \mathrm{GtCO}_{2}$ onshore and $1.1 \mathrm{GtCO}_{2}$ offshore (van den Broek et al., in press). ${ }^{7}$ Furthermore, we assume that the large aquifer in the Utsira formation in the Norwegian part of the North Sea with an estimated capacity of $42 \mathrm{GtCO}_{2}$ (Bøe et al., 2002) can become available for storage of Dutch $\mathrm{CO}_{2}$.

Based on several sources, we estimate average $\mathrm{CO}_{2}$ storage costs for onshore and offshore storage in the hydrocarbon fields and aquifers (see Table 8). We also distinguish between costs for $\mathrm{CO}_{2}$ storage when facilities of the gas production activities can be re-used, and when this is not the case (i.e. if there is a gap of more than 5 years between gas production and $\mathrm{CO}_{2}$ storage activities). Average $\mathrm{CO}_{2}$ transport costs to onshore sinks, offshore sinks, or the Utsira formation are derived from van den Broek et al., in press, a study which specifically investigated the development of the $\mathrm{CO}_{2}$ infrastructure (see Table 8).

\section{Scenario variants}

Our scenario is a modified version of the Strong Europe scenario, as defined in the WLO (Janssen et al., 2008; Farla et al., 2008; van Beek et al., 2008). Our "No limits" scenario variant uses the WLO narrative, but has no targets for $\mathrm{CO}_{2}$ emissions reductions. Building on our No limits variant, we prepare an additional eight scenario variants with various degrees of reduction commitments and options, as shown in Table 9.

Our scenario variants focus on the transport sector, but we also examine the effect on production of electricity and heat. Table 10 shows some of the bounds used in our scenario variants. A cap is set on the $\mathrm{CO}_{2}$ emissions to reduce these by $27 \%$ in 2020 and then annually by $5-6 \%$ compared to the year before, which results in total reductions of $87 \%$ in 2050 compared to 1990 level. This cap is in line with targets of $20 \%$ and $80 \%$, because we assume that relatively more $\mathrm{CO}_{2}$ emission reduction is realised in the $\mathrm{CO}_{2}$ intensive industry than in other sectors (of the $25 \mathrm{Mt}$ of industrial emissions, around

${ }^{7}$ The Slochteren field in Groningen with an estimated capacity of about 7 Gt is not included in the inventory, because it is probably unavailable for $\mathrm{CO}_{2}$ storage before 2050 (TNO, 2007a).
11-22 $\mathrm{MtCO}_{2}$ may be captured and stored per year). The equivalent $\mathrm{CO}_{2}$ emissions reduction targets are $50 \%$ in 2030 and $68 \%$ in 2040 .

Our reduction scenario variants are compatible with the EU 20/20/20 strategy for 2020 (European Commission, 2008). The Forced electric car and fuel cell variants are meant to illustrate the effect of forcing a transition to these cars and fuels.

\section{Results}

MARKAL models generate solutions with the least net present value of total system cost within the scenario bounds. Our model runs up to 2050 for purposes of optimisation, but in this chapter, we show results up to 2040. Due to high investment costs of lowor zero emission cars, a shift in fuels is the cheapest option to realise direct $\mathrm{CO}_{2}$ emissions reductions in transportation. However, the potential for this shift is limited by energy resource constraints.

\subsection{Energy sources}

Fig. 2 shows the combined primary energy consumption for road transport, electricity and heat generation in the Netherlands in 2020 and 2040. These sectors consume around half of the total Dutch primary energy.

The No limits variant shows almost a quintupling of coal consumption. This is caused by PC electricity generation, which more than doubles, and by crude oil-based diesel and petrol being replaced by coal-based FT fuels.

In the reduction scenario variants there is a preference for cofiring biomass in electricity plants combined with coal-based FT fuel production with CCS if sufficient $\mathrm{CO}_{2}$ storage capacity is available (Utsira variant). If $\mathrm{CO}_{2}$ storage capacity is limited, a combination of wind electricity and biomass-based FT fuel production with CCS turns out to be the cheapest option. Generation of wind electricity is complemented by NGCC, as wind electricity is an intermittent source. The overall shift can be explained by the very low additional costs for CCS with FT fuel production.

The use of biomass is consistent across reduction scenario variants. While the shares of biomass converted to ethanol, FT fuel 
Table 9

Nine scenario variants used in our study.

\begin{tabular}{|c|c|}
\hline Variant name & Notable properties \\
\hline 1. No limits & $\begin{array}{l}\text { No } \mathrm{CO}_{2} \text { emissions cap, no } \mathrm{CO}_{2} \text { transport to and storage in the Utsira field, use WEO } 2009 \text { reference prices for coal, and WEO } \\
2009450 \mathrm{ppm} \text { prices for other fossil energy sources }\end{array}$ \\
\hline 2. Aggregate reduction & $\begin{array}{l}\text { No limits }+\mathrm{CO}_{2} \text { emissions cap of } 80 \% \text { vs. } 1990 \text { levels in } 2020 \text {, dropping to } 20 \% \text { in } 2050 \text {, applied to the total of emissions of } \\
\text { power generation and transportation, use WEO } 2009450 \text { ppm prices for all fossil energy sources }\end{array}$ \\
\hline 3. Sectoral reduction & $\begin{array}{l}\text { No limits }+\mathrm{CO}_{2} \text { emissions cap of } 80 \% \text { vs. } 1990 \text { levels in } 2020 \text {, dropping to } 20 \% \text { in } 2050 \text {, applied separately to transportation and } \\
\text { to power generation, use WEO } 2009450 \text { ppm prices for all fossil energy sources }\end{array}$ \\
\hline 4. $95 \mathrm{~g} \mathrm{CO}_{2} / \mathrm{km}$ in 2020 & $\begin{array}{l}\text { Aggregate reduction }+ \text { require average car fleet to emit } \leq 116 \mathrm{~g} \mathrm{CO}_{2} / \mathrm{km} \text { in } 2020 \text { and } \leq 95 \mathrm{~g} \mathrm{CO}_{2} / \mathrm{km} \text { from } 2030 \text {, simulating } \\
\text { regulation } \mathrm{EC} / 2009 / 443^{\mathrm{a}}\end{array}$ \\
\hline 5. Forced electric car & Aggregate reduction + minimum $25 \%$ market share for electric cars in 2020 , rising to $90 \%$ in 2050 \\
\hline 6. Forced fuel cell car & Aggregate reduction + minimum $25 \%$ market share for fuel cell cars in 2020 , rising to $90 \%$ in 2050 \\
\hline 7. Utsira & $\begin{array}{l}\text { Aggregate reduction+allow } \mathrm{CO}_{2} \text { transport to and storage in the Utsira field, giving effectively unlimited capacity for } \mathrm{CO}_{2} \\
\text { storage }\end{array}$ \\
\hline 8. Halved biomass & Aggregate reduction + available biomass is reduced by half over the entire model timeframe. \\
\hline 9. Cheaper oil & Aggregate reduction + price of oil reduced to $9.4 € / G J$ in 2020 and $8.0 € / G J$ in 2030 and later \\
\hline
\end{tabular}

${ }^{\mathrm{a}}$ We use a delay to account for vehicle lifespan, because the EU regulation requires that new cars emit $\leq 95 \mathrm{~g} \mathrm{CO} / \mathrm{km}$ in 2020 .

Table 10

Emissions limits and minimum vehicle shares in the Netherlands in our scenario variants.

\begin{tabular}{|c|c|c|c|c|c|c|}
\hline MARKAL bound & 1990 & 2005 & 2010 & 2020 & 2030 & 2040 \\
\hline $\mathrm{CO}_{2}$ emissions power + transport (Mtonne/year) & 93 & - & - & 68 & 35 & 21 \\
\hline $\mathrm{CO}_{2}$ emissions transport (Mtonne/year) & 21 & - & - & 17 & 10 & 7 \\
\hline Average car emissions $\left(\mathrm{g} \mathrm{CO}_{2} / \mathrm{km}\right)$ & $\mathrm{n} / \mathrm{a}$ & $\mathrm{n} / \mathrm{a}$ & $\mathrm{n} / \mathrm{a}$ & 116 & 95 & 95 \\
\hline Forced share of electric/fuel cell cars (\%) & 0 & 0 & 0 & 25 & 50 & 75 \\
\hline
\end{tabular}

and electricity shifts with the exact scenario variant, all available biomass is used in our optimisations. Further analysis shows that if a nuclear option is introduced, wind and natural gas are partially replaced by nuclear power. Adoption of electric cars does not lead to an increase in electricity generation capacity, because most of the charging in our model takes place in off-peak times of the day.

In all reduction scenario variants, no PC plants are built with CCS, but $30-45 \%$ of PC plants are later retrofitted with CCS. IGCC is used only in the Utsira variant, where ample $\mathrm{CO}_{2}$ storage capacity is available.

The share of renewables in total energy resources is larger than $20 \%$ in 2020 in all of the reduction scenario variants, except the Utsira variant. In the reduction scenario variants, FT fuel plants co-produce $11-21 \mathrm{PJ}$ of base load electricity, or $2-4 \%$ of total electricity.

\subsection{Fuels and vehicles}

Fig. 3 shows the transportation fuels consumed in our scenario variants in 2020 and 2040. In all scenario variants except the Cheap oil variant, we observe a shift to imported ethanol and FT diesel from regular diesel and petrol derived from oil. By 2020, the cheapest overall transportation system uses less than 50\% crude oil derived fuel, and after 2030, oil is not used at all for transportation. This shift is entirely due to the projected oil price of $10 € / \mathrm{GJ}(90 \$ / \mathrm{bbl})$, because oil refining costs have a very limited share of the total cost of diesel and petrol. The partial shift in 2020 is due to limited availability of biomass, except in the No limits variant, where FT fuel is produced entirely from coal.

In the Cheap oil variant, oil retains a significant market share combined with FT fuel made from biomass with CCS to reduce $\mathrm{CO}_{2}$ emissions. In this variant, biomass is used for electricity generation instead of producing fuels.

Diesel, biodiesel, and FT diesel are used in buses, trucks, and vans, which together account for almost half of the total fuel consumed. Bio-ethanol is the preferred fuel for cars. Substituted bio-ethanol in 2020 is between 50 and $170 \mathrm{PJ} /$ year, which would require between 2400 and $8000 \mathrm{~km}^{2}$ (at an average yield of

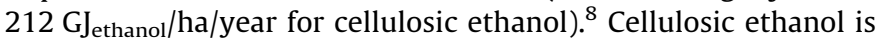
used exclusively in the 2020-2030 timeframe, as it has higher yield per available amount of biomass. However, we also observe a switch back to sugar cane ethanol in later years as the availability of biomass increases. This is because of competition in the model between sugar cane and cellulosic ethanol, with lower cost for sugar cane and more efficient production for cellulosic ethanol. In reality, these ethanol production technologies not interchangeable, as feedstocks for cellulosic ethanol can be grown on a wider range of soil types and climates.

Substituted FT production capacity in 2020 ranges up to $288 \mathrm{PJ} /$ year, replacing up to 160,000 bbl of crude oil per day. In the No limits variant, FT fuel is entirely produced from coal without CCS. In all reduction scenario variants, FT fuel is produced from a varying mix of coal and biomass, with full use of CCS. Methanol and DME did not appear in any of our least-cost configurations.

Total secondary energy used in cars in the Forced electric car variant declines, because the energy efficiency of electric vehicles is higher than of regular cars. However, conversion efficiency of producing electricity in a power plant is lower than the efficiency of oil refining or FT production. The resulting total primary energy consumption is still lower in the Forced electric car variant (compare Fig. 2 with Fig. 3 or 4 ). The same applies mutatis mutandis to the Forced fuel cell car variant. This is a shift of energy losses, and related $\mathrm{CO}_{2}$ emissions, from car drivers to fuel producers, which allows for larger volumes of CCS.

Fig. 4 shows the same total fuel consumption as Fig. 3 by vehicle type. Buses and hybrid vans have such a small share in total fuel consumption that we omitted them from Fig. 4.

Fig. 4 indicates that our model avoids hybrid, electric or fuel cell vehicles, because of the high investment cost of alternative drivetrains. Diesel cars also disappear in all reduction scenario

\footnotetext{
${ }^{8}$ Compare to a total land area of the Netherlands of $41,500 \mathrm{~km}^{2}$.
} 


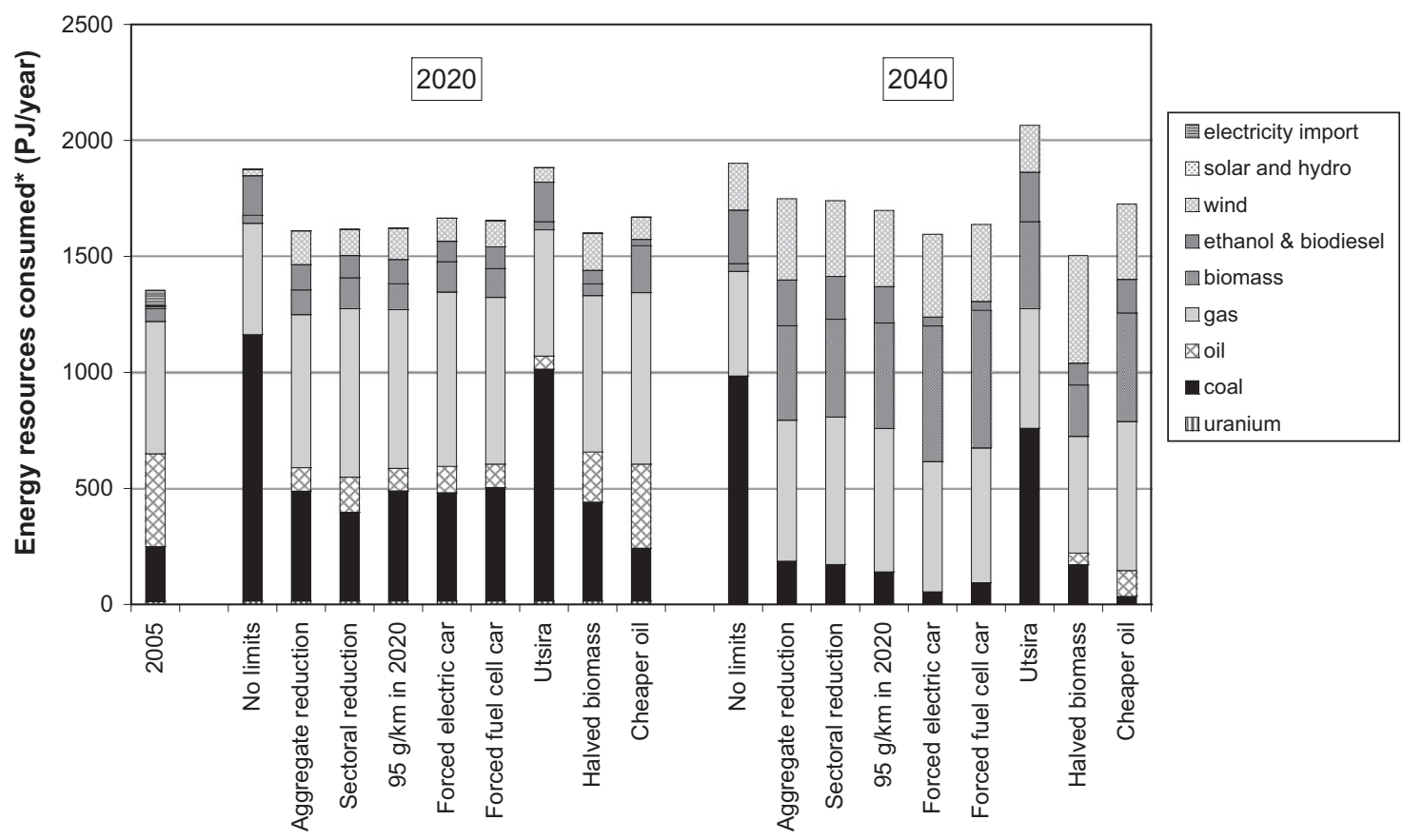

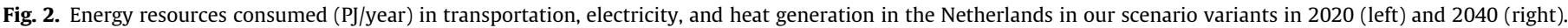
*1 PJ electricity generated by wind, solar or hydro $=1 \mathrm{PJ}$ in this graph.

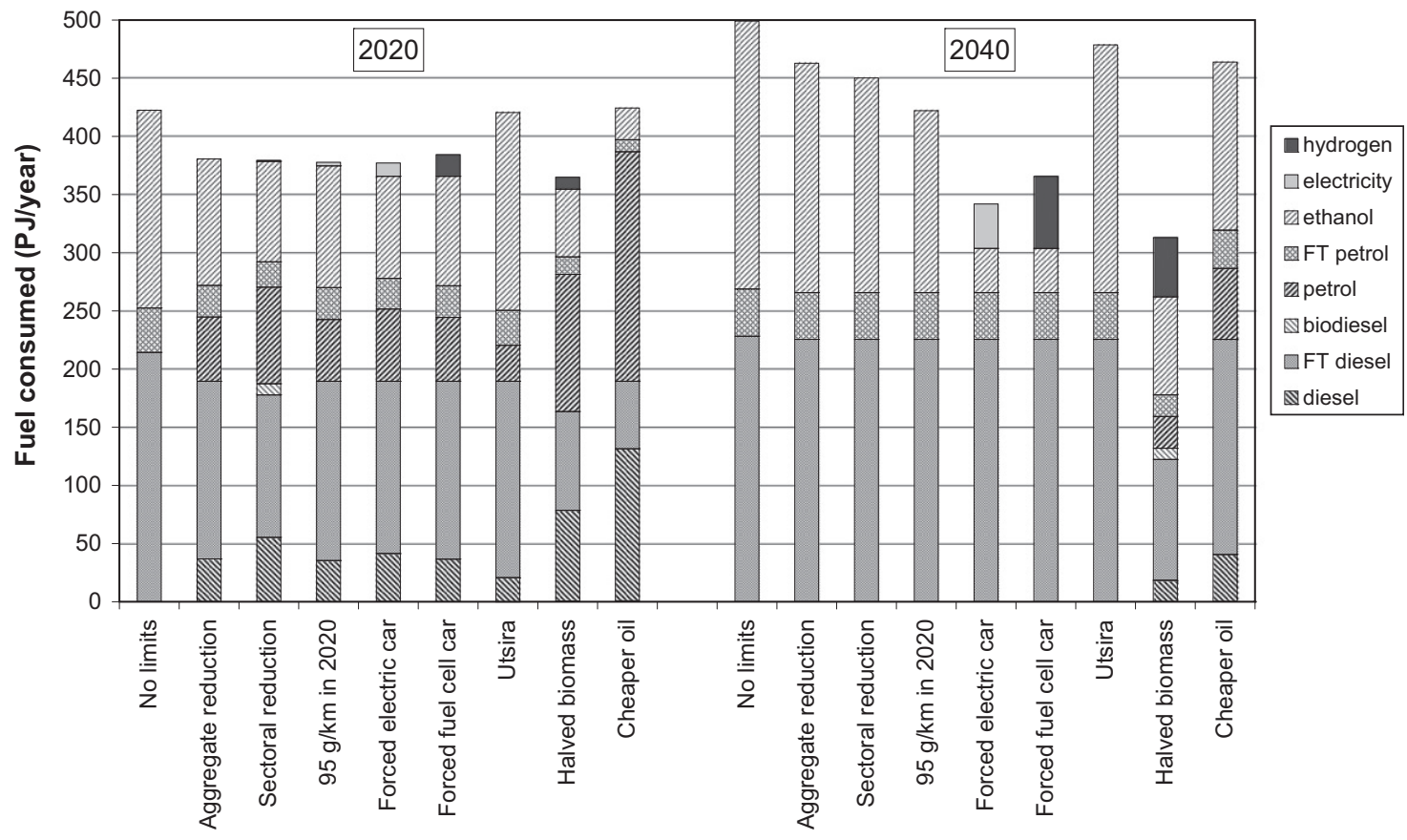

Fig. 3. Transportation fuels consumed (PJ/year) in the Netherlands in our scenario variants in 2020 (left) and 2040 (right).

variants due to higher cost of diesel, FT diesel, biodiesel, and diesel-fuelled cars compared to petrol, FT petrol, ethanol, and petrol-fuelled cars.

Series hybrid cars are used as the most cost-effective option to reduce fuel demand when not enough low-emission fuel options (biofuels and/or CCS capacity) are available to stay within the $\mathrm{CO}_{2}$ emissions budget while using regular cars. We tested this further by increasing the relative price of ethanol vs. biomass intermediates drives, in which case adoption of hybrid cars increases because the model seeks to accommodate the petrol-fuelled fleet with less biomass resources. In the $95 \mathrm{~g} \mathrm{CO}_{2} / \mathrm{km}$ in 2020 variant, average vehicle efficiency is improved by more than $20 \%$ in 2020 , which complements the EU 20/20/20 strategy.

Unless fuel cell cars are forced in, emergence of hydrogen as a transportation fuel in our model is primarily due to hydrogenpowered vans. This is because vans, like many fleet vehicles, are driven large distances compared to private passenger cars. Fuel costs therefore account for a larger share of total driving costs in vans than for regular cars, and vans are therefore switched before cars. 


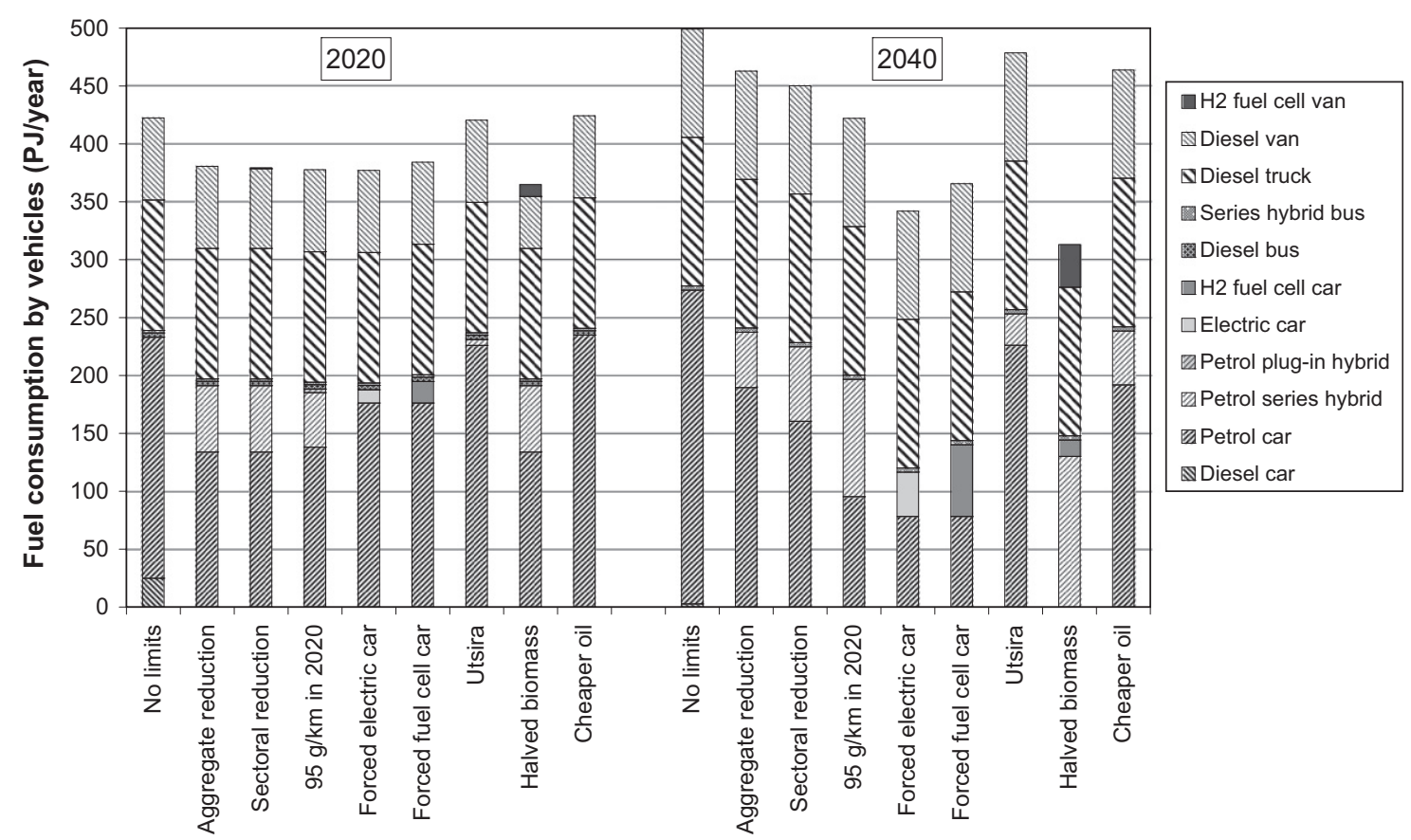

Fig. 4. Transportation fuel consumed by vehicles (PJ/year) in the Netherlands in our scenario variants in 2020 (left) and 2040 (right).

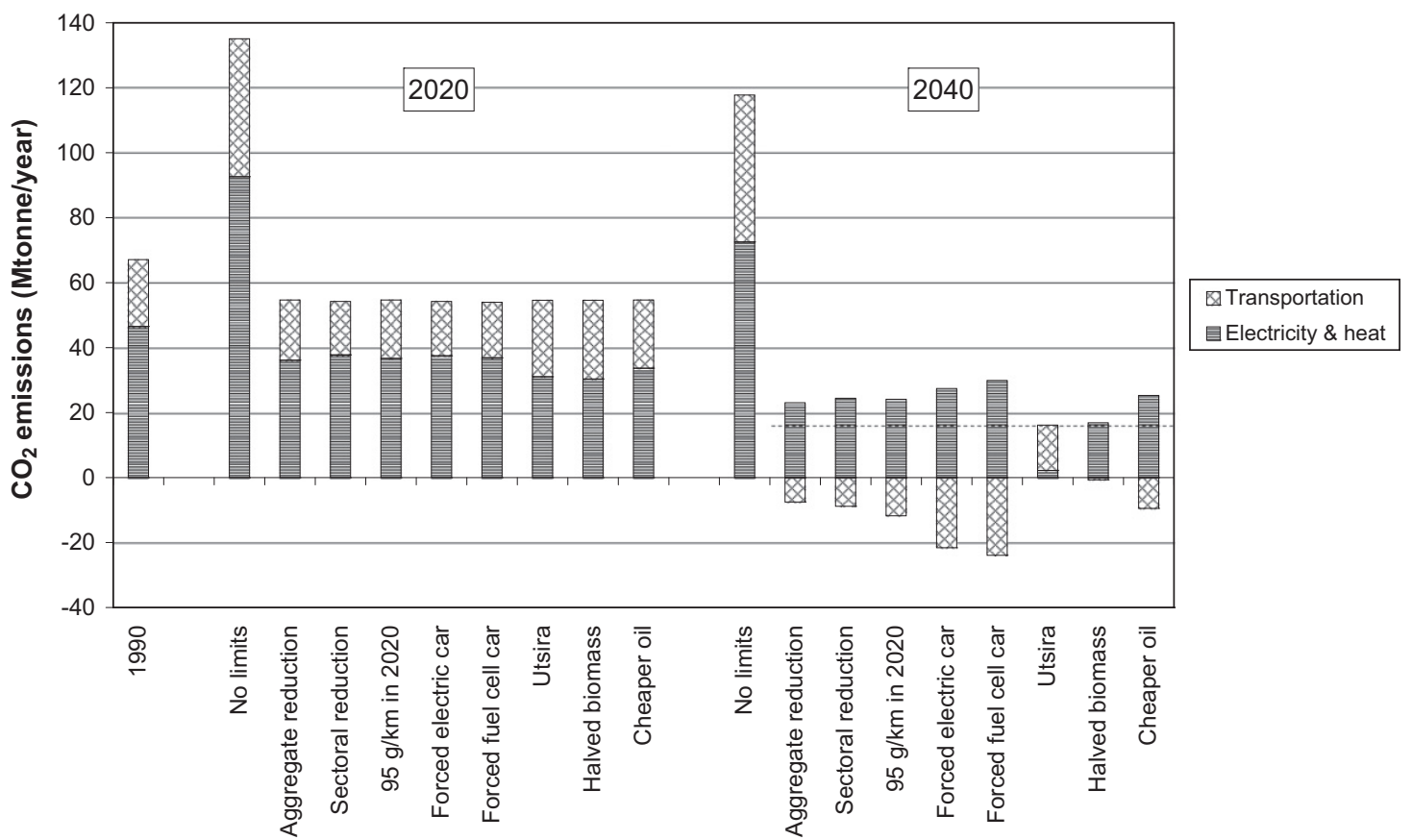

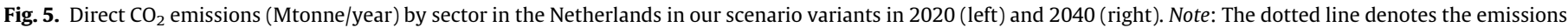
cap level for 2040 in our scenario variants.

\section{3. $\mathrm{CO}_{2}$ emissions}

Fig. 5 shows that direct $\mathrm{CO}_{2}$ emissions in transportation and electricity production in the No limits variant increase by $100 \%$ in 2020 over 1990 levels, mostly due to the increase in consumption of coal. $\mathrm{CO}_{2}$ emissions in the No Limits variant decline after 2020, as do emissions in reduction scenario variants.

Direct $\mathrm{CO}_{2}$ emissions of transportation are reduced almost to zero or negative in most of our reduction scenario variants. This is a result of biomass-based FT fuel or hydrogen production with
CCS, which has net negative $\mathrm{CO}_{2}$ emissions, combined with bioethanol which has very low emissions.

Indirect emissions of GHG, due to mining of coal, recovery of oil and gas, and farming, were limited to around $10 \%$ of total emissions in 2005. Fig. 6 shows that indirect GHG emissions both increase in absolute terms and take a larger share in the total emissions. Indirect GHG emissions are $34-54 \%$ of total emissions caused by the Netherlands in 2040. These indirect emissions are attributed to the countries that produce the energy resources. 
Direct \& indirect GHG emissions

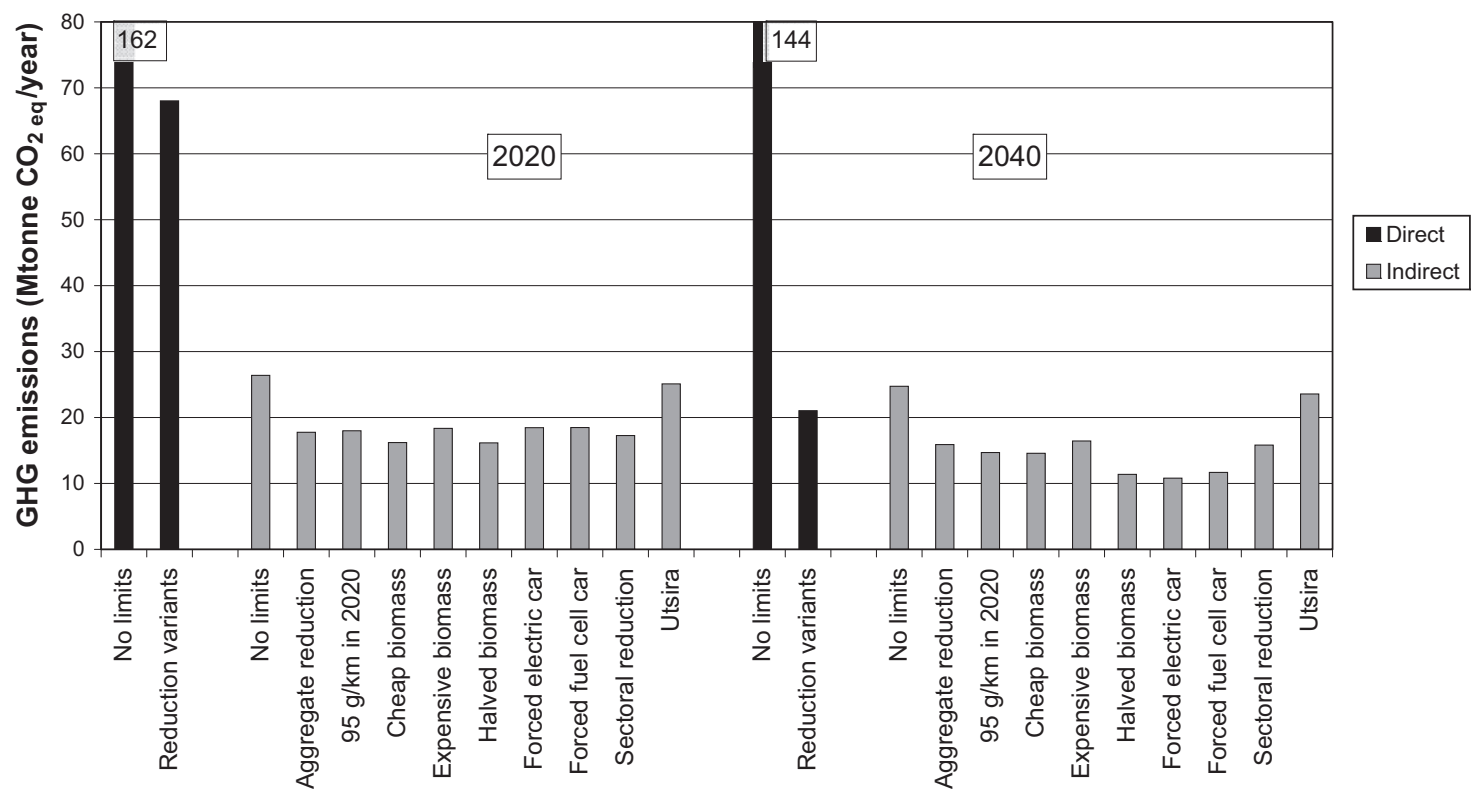

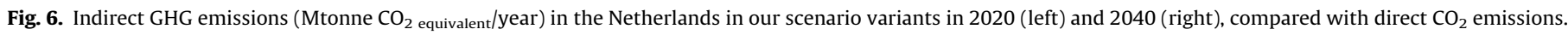

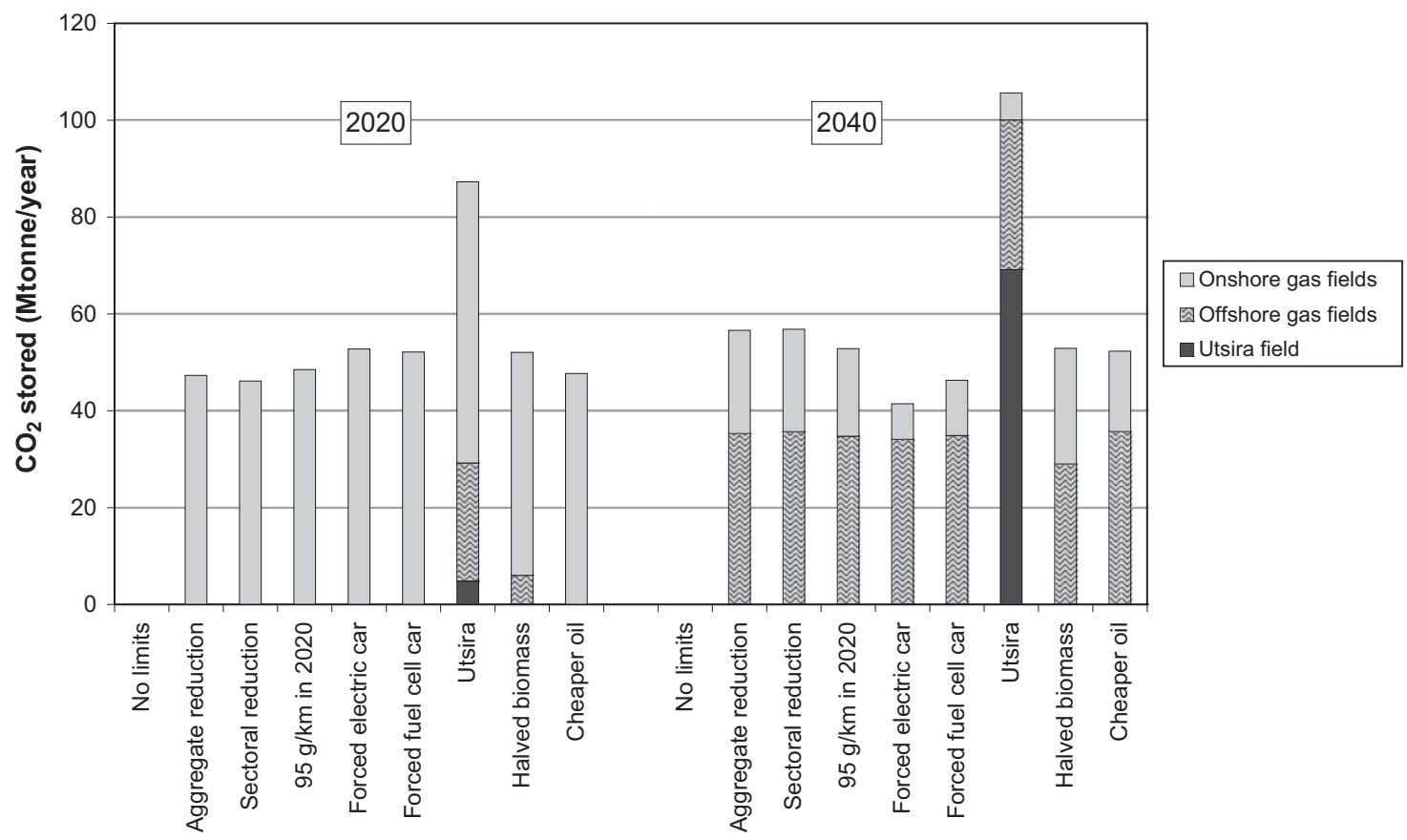

Fig. 7. $\mathrm{CO}_{2}$ stored in underground formations (Mtonne/year) in the Netherlands in our scenario variants in 2020 (left) and 2040 (right).

The increase is caused primarily by the use of coal and ethanol, which substitute crude oil-derived fuels that have much lower indirect emissions (see Table 6). Indirect emissions are lowest in variants with low average fuel consumption of vehicles.

The amount of $\mathrm{CO}_{2}$ stored underground varies with the optimal timing of large scale use of CCS. Fig. 7 shows that use of offshore storage sites is postponed unless sufficient storage potential is available.

\subsection{Costs and investment}

Fig. 8 shows the marginal $\mathrm{CO}_{2}$ abatement costs. As the $\mathrm{CO}_{2}$ emissions reduction target exceeds $30 \%$, marginal cost of abatement are $100-150 € /$ tonne $\mathrm{CO}_{2}$ across our reduction scenario variants, as long as the supply of biomass expands at a sufficient rate. A shortfall of biomass (without having the Utsira field available for CCS) more than doubles abatement costs because more expensive vehicles must be used to attain $\mathrm{CO}_{2}$ limits.

Due to the nature of linear programming optimisation, the marginal abatement costs in Fig. 8 do not include the costs of the electric and fuel cell cars in their respective Forced car scenario variants. The marginal costs for these scenario variants would be around $400 € /$ tonne if electric and fuel cell vehicles were included, as demonstrated by the marginal costs in the Halved biomass variant after 2040 (where hydrogen fuel cell cars are the marginal reduction option). 


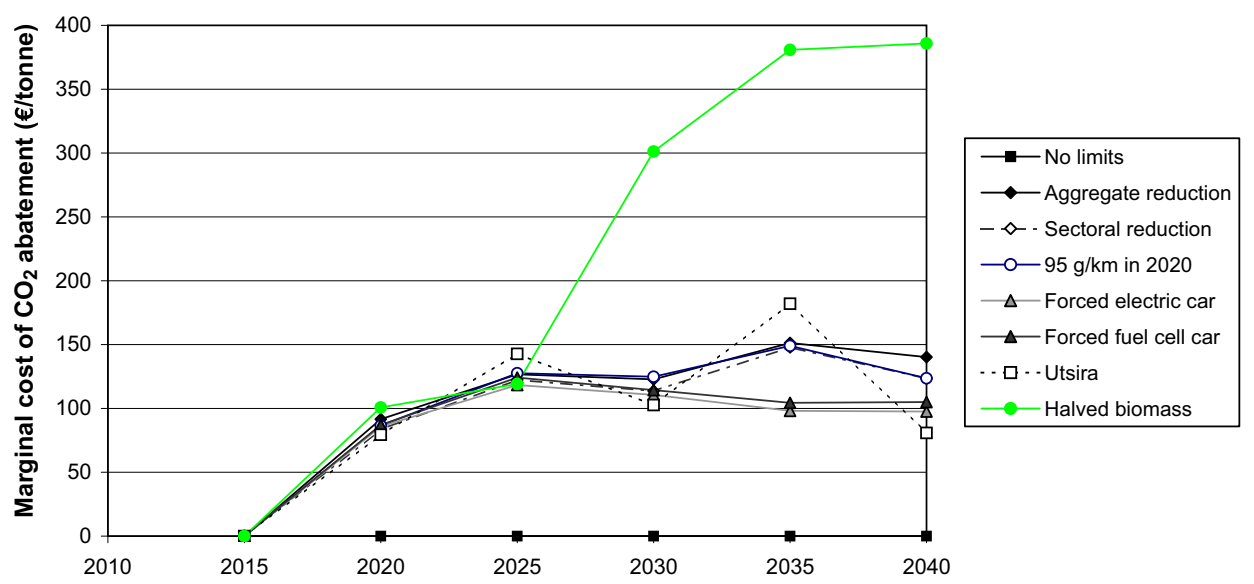

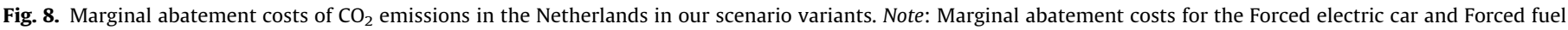

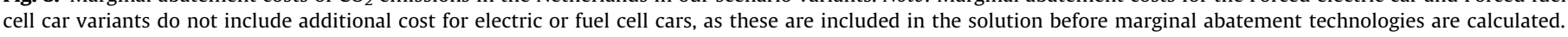

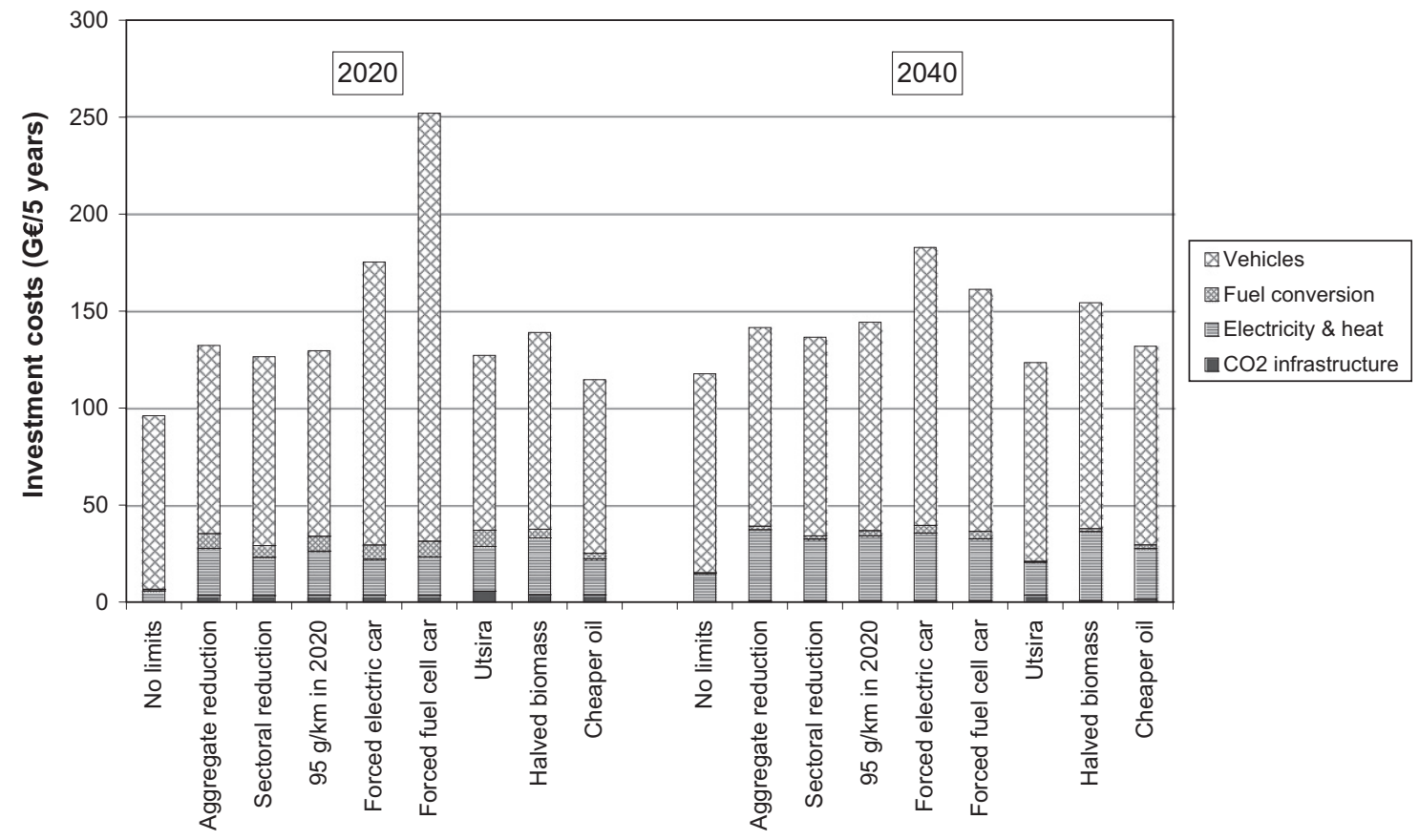

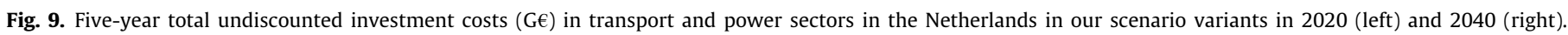
Note: These costs are not annualised over the life time of technologies, and vehicle investment does not include purchase of trucks.

With Fig. 8 in mind, we optimised the same system using a carbon tax instead of an emissions reduction target. Two carbon tax development paths were used; one rising from $46 € /$ tonne $\mathrm{CO}_{2}$ in 2020 to $73 € /$ tonne in 2040 , and another rising exponentially from $23 € /$ tonne in 2020 to $201 € /$ tonne in 2040.

Optimisations using a rising carbon tax instead of a $\mathrm{CO}_{2}$ emissions cap show less $\mathrm{CO}_{2}$ emissions reductions around 2020, but this difference disappears by 2040. A switch in transportation fuel is again the preferred reduction strategy, using ethanol and FT fuel from coal, with an extreme preference for FT fuel from biomass by 2040 if the carbon tax rises exponentially.

Fig. 9 shows total investment into the development of the Dutch transport and power sectors until 2040. These costs do not include opportunity costs and port facilities.

The investment to develop the Dutch transport and power sectors ranges upwards from 19 billion euro/year. More than $80 \%$ of the investments are for periodic replacement of vehicles, which already occurs today and is done by consumers. This is in line with results from other studies (e.g. IEA, 2009). In most scenario variants, vehicle replacement in the Netherlands costs 18-21 billion euro/year. The exceptions are the Forced electric car and Forced fuel cell car variants, where investments into cars are 2545 billion euro/year.

Investment into electricity generation in the No Limits variant compared to the reduction scenario variants, is higher in 2015 and then lower until 2030, and also lower in total. Investment into electricity generation capacity is the lowest in the No Limit and Utsira variants where coal-fired power plants can be used. In the other variants, more expensive and variable wind electricity is used. This intermittent wind electricity is complemented by electricity from NGCC, which increases the effective cost of wind electricity.

Not including the forced car variants, total investment into transport and power sectors until 2040 ranges between 19 and 31 
billion euro/year, or 3.1-4.5\% of Dutch GDP ${ }^{9}$ as projected in the WLO Strong Europe scenario (Janssen et al., 2008). At least 19 billion euro/year of this will be invested in any year in any scenario variant, and over $90 \%$ of that is for replacing cars that reach end of life. The difference between the No limits and the other non-forced car reduction variants is 4-7 billion euro/year, equivalent to $0.5-1.2 \%$ of GDP. This is mostly invested in cars and electricity generation capacity.

Higher investment can have both positive and negative effects on economic development (also see Strachan and Kannan, 2008) However, we did not calculate possible externalities, economic spinoffs, or indirect effects resulting from the changes in the transportation and power sectors. Investments should therefore be interpreted indicating the order of magnitude of the effort required.

\section{Discussion}

Modelling inevitably requires assumptions and imperfect data. We discuss the impact of some important assumptions below.

\subsection{Modelling approach}

We deliberately do not put a limit to the construction rate of conversion capacity in our model, choosing instead to show the optimal configuration. In reality, design difficulties, financing requirements, planning produces, construction delays, dependence on infrastructure such as port facilities, vested interests, and other factors constrain the speed at which existing cars and fuels can be substituted, and infrastructure built. The large number of FT plants, high share of ethanol, high uptake of CCS and complete switch away from crude oil that we found may therefore be restricted by many other factors in the real world.

In addition, consumers, producers, and regulators may have other criteria to choose fuels and cars, such as impact on air quality, system flexibility, diversification of energy sources, technical familiarity, and/or aesthetics, none of which are taken into account in our model.

Heterogeneity in important markets is also not taken into account in our model. For example, we use one average distance per car per year. However, company-owned cars drive $45-75 \%$ more $\mathrm{km} /$ year than privately owned cars (Centraal Bureau voor de Statistiek, 2008). This can affect the trade-off between higher investment for a new car vs. lower fuel consumption and lower fuel costs. We expect a market to exist for more expensive cars with lower per km fuel costs similar to the vans in our analysis. Defining subsets of demand based on driving habits may therefore result in a better estimate of future shares of vehicles types.

Demand for electricity and transportation used in this study is exogenous, but higher electricity or transportation prices may encourage more efficient behaviour and technology development. It would therefore be preferable to expand our optimisation with demand functions. For electricity, this would incorporate the trade-off between cleaner production of electricity and more efficient end-use. For transportation, this would incorporate the trade-off between driving cars and other mobility services (modal shift).

\footnotetext{
${ }^{9}$ Dutch GDP is projected to grow by around $2.4 \% /$ year in the WLO Strong Europe scenario to around 614 billion $€$ in 2020 and 780 nillion $€$ in 2040. All numbers relative to GDP use the GDP of the year for which they are calculated.
}

\subsection{Energy resources}

Projections of future energy prices vary considerably. For example, prices of coal, oil and natural gas vary over $50 \%$ in some cases between the World Energy Outlook editions of 2009, 2008 , and 2007 (IEA, 2007, 2008b, 2009). However, many alternatives to conventional crude oil become attractive with crude oil prices ranging between 60 and $100 \$ /$ bbl (van Vliet et al., 2009; Everts, 2008). Furthermore, increased market share of these alternatives would dampen a sustained upwards movement of oil prices.

Crude oil cost represents more than $80 \%$ of the cost of petrol and diesel (van Vliet et al., 2009). By contrast, the cost of biomass or coal feedstock is $35-55 \%$ of FT fuel cost (van Vliet et al., 2009), and biomass cost is $45-55 \%$ of ethanol cost (van den Wall-Bake et al., 2009). Petrol and diesel production is therefore much more vulnerable to feedstock price shifts. Optimising the transport system is therefore most sensitive to oil prices.

Fossil and biomass resource prices used in this study are exogenous, but if oil is largely abandoned, oil prices may fall and prices of alternative energy resources are expected to rise (also depending on tax regimes). We accounted for this in the Cheap oil variant. We use oil prices from the WEO 2009450 ppm scenario in other reduction scenario variants, which take into account a large drop in oil demand but not the complete switch away from crude oil that we observe. This indicates that in each of our variants, either oil price is unrealistically high or oil consumption is unrealistically low. However, a switch away from oil is found across variants.

It may therefore be preferable to use dynamic energy resource prices based on demand, available stocks and production capacity, e.g. by using supply curves or price elasticities. However, including dynamics in energy resource supply and prices is difficult, because supply projections for biomass have a wide range and uncertainty (Hoogwijk et al., 2009; Wit and Faaij, 2008), and the sizes of remaining stocks of fossil resources are highly contentious (Zittel and Schindler, 2004). For example, Hoefnagels et al. (2009) investigated scenarios in which biomass use in the Netherlands in 2030 varies between 150 and $1450 \mathrm{PJ} /$ year.

Investigating the robustness of our results, we find that in optimisations with the price of biomass intermediates rising to $10 € / G J$, demand is equal to the potential supply, indicating that supply volume is more important than price as long as oil prices remain high.

\subsection{Technological progress and technology cost}

The timing of the introduction of more efficient and cheaper technologies in our model expansion is optimistic (see Table 1) and complements our choice not to put restrictions on speed of construction of new electricity and fuel production plants. In the event, the technologies adopted in our scenario variants do not hinge on the early availability of advanced technologies. For (cellulosic) ethanol, the same saturation of supply is found as for other biomass applications, and the same insensitivity to prices applies.

For fuel cells, cost reductions will depend in part on future production volumes. However, expansion of existing production depends on adoption, which is hindered by current high costs. In case of forced adoption of fuel cell cars, we project investment into cars to double in some of the 5 year periods. However, doubling the price of cars is unlikely to meet with public enthusiasm. We therefore do not expect hydrogen fuel cell cars to be demanded in appreciable volume, and thus expect fuel cell vehicles to be less economically attractive than in our data set. As 
our model must be forced into adopting fuel cell cars even in 2040, when we assume fuel cell costs are reduced tenfold from today, our findings are insensitive to the timing of progress in fuel cells. The same rationale applies to a lesser degree to electric cars, as hybrid cars provide a channel for cost reductions of batteries.

Adoption of electric cars does not lead to significant change in electricity generation capacity. As the MARKAL-NL-UU model divides electricity demand and production into six intervals (day, evening, and night in both summer and winter), we could not analyse the effect of timing of charging of electric cars in detail. We did not analyse the effect of smart charging systems on load patterns or the mix of electricity production. We recommend more detailed analysis of the impact of charging patterns of large numbers of electric vehicles on electricity demand and resulting cost and $\mathrm{CO}_{2}$ emissions.

\subsection{Generalising our results}

We describe a case study optimising the Dutch transportation and power sectors. To generalise the results beyond the Dutch situation, we consider that the available technologies and energy resources prices should be roughly the same for industrialised countries. However, the existing (vintage) car fleet, fuel production and electricity generation capacity and structure of demand for fuel and transportation would create country-specific dynamics, particularly in the short term. Nevertheless our results agree with findings from Anandarajah and Strachan (in press) for the UK and Hedenus et al. (2010) for the global energy system.

Eventually, the existing vehicle fleets, fuel production and electricity generation plants will be replaced anyway, thus reducing their impact on long term optimisations. Assuming that biomass availability increases due to increasing global biomass trade, the major remaining differences between industrialised countries would be the long term potential for wind energy and underground carbon storage capacity, and presence of long-lived facilities like nuclear reactors and large hydroelectric dams.

Other differences between countries, like population density, infrastructure, legislation, and public policy are not part of the MARKAL-NL-UU model. We recommend further investigation into these aspects using other methods.

However, in our scenario variants, biomass, CCS, wind with NGCC, hydro and nuclear power capacity were found to be largely interchangeable for production of base load electricity with $\mathrm{CO}_{2}$ emissions reduction targets. We therefore conclude that our results can be generalised to a large extent for the transportation sector in industrialised countries, and most likely also for the interaction between the transportation and power sectors.

Across scenarios, time periods and reduction targets, our leastcost optimal configurations show a preference for biofuels and hybrid cars over electric or fuel cell cars. In addition to having lower costs, this allows for an easier transition as less infrastructure change is required to support hybrid cars than to facilitate large scale use of electric or hydrogen fuel cell cars (cf. Hendriks et al., 2005).

Furthermore, there is little difference between the aggregated reduction, sectoral reduction, and $95 \mathrm{~g} \mathrm{CO}_{2} / \mathrm{km}$ in 2020 scenario variants. This suggests that (combinations of) policy approaches that emphasize different aspects of $\mathrm{CO}_{2}$ emissions reductions, such as technology support, carbon taxes, and efficiency targets, could arrive at the same future transportation and power system.

Future feasibility studies should take into account competition for CCS storage and biomass availability. For CCS, the focus of earlier studies has been on its application in electricity, but fuel production may have a large impact on the amount of $\mathrm{CO}_{2}$ stored per year. For biomass, available supply in countries and allocation between transportation and power sectors has a large impact on $\mathrm{CO}_{2}$ abatement costs.

\section{Summary and conclusions}

We examined future interactions between the transport and power sectors in the Netherlands using the MARKAL-NL-UU model. We simultaneously examined competition for energy resources, development of CCS, and co-evolution of electricity and fuel conversion capacity.

The existing model data set is expanded with 36 types of cars, buses, trucks, and vans that can use 9 different fuels produced with 23 fuel conversion technologies. New fuel conversion technologies are introduced up to 2020 and new vehicle technologies up to 2030. Our model optimises total system cost over a long time horizon, without constraints on construction of new power plants and fuel conversion plants. Transportation and power demand, availability of technologies over time, as well as supply and price of energy resources are included exogenously. Our scenario is based on the WLO, using WEO 2009 energy prices. We create nine scenario variants, including one without emissions reductions, and two with forced market share of electric and fuel cell cars, respectively.

Use of oil decreases considerably in all scenario variants. Our "no limits" variant shows almost a quintupling of coal consumption due to increased use of coal in electricity generation and to produce FT fuels. As no CCS is used, this caused a $73 \%$ increase over 1990 levels of $\mathrm{CO}_{2}$ emissions by 2020 .

Reduction scenario variants show various way of reducing $\mathrm{CO}_{2}$ emissions by $20 \%$ in $2020,50 \%$ in 2030 and $68 \%$ in 2040 compared to 1990 levels. We observe that the lowest overall costs are achieved by making reductions in transportation first and using relatively expensive options for emissions reduction in electricity if needed. Use of wind electricity, biofuels and biomass increases significantly across our reduction scenario variants.

We find a preference for using biofuels to reduce emissions from transportation, either by using ethanol or by FT fuels produced with CCS. Biomass potential is fully used in all of our reduction scenario variants, also at biomass feedstock prices up to $10 € / \mathrm{GJ} . \mathrm{CO}_{2}$ storage potential is also fully used. Series hybrids are used if insufficient low-carbon fuels are available. Electric cars and fuel cell cars appear only when forced into the model solution.

Depending on the availability of biomass and carbon storage capacity, electricity is produced from biomass, coal with CCS, or wind turbines complemented with NGCC. Combining production of FT diesel with CCS is found to be more cost-effective than applying CCS in electricity production.

However, as direct $\mathrm{CO}_{2}$ emissions are reduced by $68 \%$ in 2040 , indirect GHG emissions rise to 11-25 Mtonne/year, thereby overtaking direct emissions.

Long term costs of $\mathrm{CO}_{2}$ emissions abatement rise to 100-150 $€ /$ tonne for reduction targets between $30 \%$ and $70 \%$. These costs are consistent across reduction scenario variants, provided that sufficient biomass and/or CCS are available. If this is not the case, abatement costs may rise to $400 € /$ tonne $\mathrm{CO}_{2}$. The difference between investment in the No limits and the other non-forced car reduction variants is calculated at 4-7 billion euro/year, equivalent to $0.5-1.2 \%$ of GDP. This is mostly invested in cars and electricity generation capacity.

Based on our result we argue that evolutionary alternatives such as hybrid cars and biofuels are both less complex in terms of adaptation and infrastructure and less costly than an invasive transition using electric cars, fuel cell cars and required 
infrastructure of our road transportation. Furthermore, these options can still attain deep reductions in GHG emissions as well as reduce oil consumption.

Electrified drivetrains (full electric, series hybrid or fuel cell powered) become dominant in every scenario. These should therefore be developed further, especially in niche markets where series hybrids perform best in fuel consumption and co-benefits, and where fuel consumption has a relatively high share in TCO, i.e. city buses, taxis, and delivery vans.

Our analysis also presents a case for steadily making transport GHG emissions standards more stringent, as there are multiple technology pathways that make lower emissions attainable. Tightening emissions standards at a smart pace would drive innovation and implementation of these options, facilitating cost reductions without favouring specific technologies or market parties. To justify the required research and investment, such standards should be set at a supra-national level (e.g. EU or OECD), thereby ensuring a large market.

Competition between transportation and power sectors for biomass and CCS storage capacity should be taken into account in future feasibility studies. We recommend further research on the potential impacts of large numbers of electric vehicles on electricity load patterns, and on non-cost barriers to and impacts of a large shift in fuels and cars used transportation.

\section{Acknowledgements}

The authors wish to thank Gerben Geilenkirchen of the Planbureau voor de Leefomgeving (PBL) for sharing their transportation demand projections, and Ric Hoefnagels of Science, Technology and Society at Utrecht University for his insights on energy prices. We also wish to thank two anonymous reviewers for their suggestions to improve the manuscript. This study was carried out as part of the research projects Quantified backcasting: methodological design of transition strategies in the area of sustainable transportation chains and Dutch national research programme on $\mathrm{CO}_{2}$ capture and storage (CATO). It was financially supported by NWO, SenterNovem, the Dutch Ministry of Economic Affairs (EZ), and CATO consortium partners (see www. CO2cato.nl).

\section{References}

Anandarajah, G., Strachan, N., Interactions and implications of renewable and climate change policy on UK energy scenarios. Energy Policy, in press. Available from: 〈http://dx.doi.org/10.1016/j.enpol.2010.06.042 〉.

ANWB, 2009. Autokosten nieuwe auto's. Available from: 〈http://www.anwb.nl/ auto/rijden/wat-kost-autorijden,/nieuwe-auto.html > (accessed 23.04.09).

Berglund, C., Söderholm, P., 2006. Modeling technical change in energy systems analysis: analyzing the introduction of learning-by-doing in bottom-up energy models. Energy Policy 34 (12), 1344-1356 Available from:〈http://dx.doi.org/ 10.1016/j.enpol.2004.09.002

Bøe, R., Magnus, C., Osmundsen, P.T., Rindstad, B.I., 2002. Geological storage of $\mathrm{CO}_{2}$ from combustion of fossil fuel. Summary Report of the GESTCO Project. Geological Survey of Norway, Trondheim, NO.

BOVAG-RAI, 2006. Mobiliteit in cijfers auto's 2006. Available from: <http://www. nnmedia.nl/bovag-rai.nl/bovag/2006/nl/auto >.

Campbell, C.J., 2006. The Rimini Protocol an oil depletion protocol: heading off economic chaos and political conflict during the second half of the age of oil. Energy Policy 34 (12), 1319-1325 Available from: 〈http://dx.doi.org/ $10.1016 /$ j.enpol.2006.02.005 >

CASTOR Project, 2004. European Castor project on the capture and geological storage of $\mathrm{CO}_{2}$. Available from:〈https://www.co2castor.com/

Centraal Bureau voor de Statistiek, 2008. Gemiddelde jaarkilometrage van personenauto's. Available from: 〈http://statline.cbs.nl/StatWeb/publication/ $? \mathrm{VW}=\mathrm{T} \& \mathrm{DM}=\mathrm{SLNL} \& \mathrm{PA}=71107 \mathrm{ned} \& \mathrm{D} 1=0 \& \mathrm{D} 2=\mathrm{a} \& \mathrm{D} 3=1-3 \& \mathrm{D} 4=0 \& \mathrm{D} 5=0 \& \mathrm{D} 6=0,2$, $5 \& H D=090615-1533 \& H D R=T, G 4, G 3, G 1, G 2 \& S T B=G 5>$ (accessed 18.06.09).

Centraal Bureau voor de Statistiek, 2009a. Aardolieproducten; aanbod, verbruik en voorraad. Available from: <http://statline.cbs.nl/StatWeb/publication/?VW= $\mathrm{T} \& D M=S L N L \& P A=80100 N E D \& D 1=2 \& D 2=7,14 \& D 3=70,87,104,155,172,189,206$ $\& \mathrm{HD}=091022-1608 \& \mathrm{HDR}=\mathrm{G} 2 \& \mathrm{STB}=\mathrm{T}, \mathrm{G} 1>$ (accessed 21.09.09).
Centraal Bureau voor de Statistiek, 2009b. Luchtverontreiniging, emissies door mobiele bronnen. Available from: 〈http://statline.cbs.nl/StatWeb/publication/ ?VW=T\&DM=SLNL\&PA=7062\&D1 =7\&D2=0,5-6,10-11,14-17\&D3=0,5,10,12,15,1 $\& H D=090811-1537 \& H D R=T, G 1 \& S T B=G 2>$ (accessed 11.08.09).

Centraal Bureau voor de Statistiek, 2009c. Luchtverontreiniging, emissies door wegverkeer. Available from: 〈http://statline.cbs.nl/StatWeb/publication/?VWT\& $\mathrm{DM}=\mathrm{SLNL} \& \mathrm{PA}=7063 \& \mathrm{D} 1=24,56 \& \mathrm{D} 2=10,19,26 \& \mathrm{D} 3=2,7,12,14,17,1 \& \mathrm{HD}=090615-1$ 640\&HDR=T,G1\&STB=G2〉〈http://statline.cbs.nl/StatWeb/publication/?VW=T\& $\mathrm{DM}=\mathrm{SLNL} \& \mathrm{PA}=7063 \& \mathrm{D} 1=24,56 \& \mathrm{D} 2=13-17,20-24,27-31 \& \mathrm{D} 3=2,7,12,14,17,1 \& \mathrm{HD}=$ 090615-1909\&HDR=T,G1\&STB=G2> (accessed 18.06.09).

Centraal Bureau voor de Statistiek, 2009d. Motorvoertuigen; bedrijfsvoertuigen per periode naar technische kenmerken. Available from: $<$ http://statline.cbs. nl/StatWeb/publication/?VW=T\&DM=SLNL\&PA=71407NED\&D1=50-54\&D2=1$5 \& \mathrm{D} 3=0,2,4,7,1 \& \mathrm{D} 4=0 \& \mathrm{HD}=090615-1905 \& \mathrm{HDR}=\mathrm{G} 3, \mathrm{G} 1, \mathrm{~T} \& \mathrm{STB}=\mathrm{G} 2\rangle \quad$ (accessed 18.06.09).

Centraal Bureau voor de Statistiek, 2009e. Motorvoertuigen; personenauto's per periode naar technische kenmerken. Available from: <http://statline.cbs.nl/ StatWeb/publication/?VW=T\&DM=SLNL\&PA=71405NED\&D1=36-37,48-52\&D2= $0,2,5,7,1 \& D 3=0 \& H D=090615-1516 \& H D R=T \& S T B=G 1, G 2>$ (accessed 18.06.09).

Chacón, F.A.T., 2004. Techno-Economic Assessment of Biofuel Production in the European Union, Energy Policy and Energy Systems Department. Fraunhofer Institut Systemtechnik und Innovationsforschung, Karlsruhe, p. 117.

Christensen, N.P., Holloway, S., 2004. Geological storage of $\mathrm{CO}_{2}$ from combustion of fossil fuel. Summary Report, second ed. GESTCO Project, Brussel, Project no. ENK6-CT-1999-00010. Available from:〈http://www.geus.dk/program-areas/ energy/denmark/co2/GESTCO_summary_report_2ed.pdf $\rangle$.

Cramer, J., Duurzame productie van biomassa, P., 2006. Criteria voor duurzame biomassa productie. Task Force Energietransitie. Available from: <http:// www.snm.nl/pdf/1000_060714biomassarapportciecramerjuli2006.pdf $\rangle$.

Damen, K., van Troost, M., Faaij, A.P.C., Turkenburg, W.C., 2007. A comparison of electricity and hydrogen production systems with $\mathrm{CO}_{2}$ capture and storage-Part B: chain analysis of promising CCS options progress in energy and combustion science. 33(6), 580-609. Available from: 〈http://dx.doi.org/ 10.1016/j.pecs.2007.02.002 >.

Damen, K.J., Faaij, A.P.C., Turkenburg, W.C., 2009. Pathways towards large-scale implementation of $\mathrm{CO}_{2}$ capture and storage: a case study for the Netherlands. International Journal of Greenhouse Gas Control 3 (2), 217-236 Available from: 〈http://dx.doi.org/10.1016/j.ijggc.2008.09.005 >.

de Feber, M.A.P.C., Gielen, D.J., 2000. Biomass for greenhouse gas emission reduction task 7: energy technology characterisation. ECN Beleidsstudies, Petten, NL, ECN-C-99-078. Available from:〈http://www.ecn.nl/publicaties/ default.aspx?nr=ECN-C-99-078 >.

de Feber, M.A.P.C., Schaeffer, G.J., Seebregts, A.J., Smekens, K.E.L., 2003. Enhancements of Endogenous Technology Learning in the Western European MARKAL Model; Contributions to the EU SAPIENT Project. ECN Beleidsstudies, ECN-C03-032.

de Wit, M.P., Faaij, A.P.C., 2007. Impact of hydrogen onboard storage technologies on the performance of hydrogen fuelled vehicles: a techno-economic well-to-whee assessment. International Journal of Hydrogen Energy 32 (18) 4859-4870 Available from:〈http://dx.doi.org/10.1016/j.ijhydene.2007.07.051〉.

de Wit, M.P., Faaij, A.P.C., 2008. Biomass Resources Potential and Related Costs: Assessment of the EU-27, Switzerland, Norway and Ukraine, REFUEL, ECN. Available from: 〈http://www.refuel.eu/fileadmin/refuel/user/docs/REFUEL_ D9.pdf $>$.

Dornburg, V., Vuuren, D.V., van de Ven, G., Langeveld, H., Meeusen, M., Banse, M., Oorschot, M.v., Ros, J., van den Born, G.J., Aiking, H., Londo, M., Mozaffarian, H., Verweij, P., Lysen, E., Faaij, A., 2010. Bioenergy revisited: key factors in global potentials of bioenergy. Energy and Environmental Science Available from: $\langle$ http://dx.doi.org/10.1039/B922422J $\rangle$.

e-Traction, 2009. Operational Efficiency. Available from: 〈http://www.e-traction. com/operational_efficiency.htm $>$ (accessed 15.01.09).

Edwards, R., Larivé, J.-F., Mahieu, V., Rouveirolles, P., 2006. Well-to-Wheels Analysis of Future Automotive Fuels and Powertrains in the European Context. Joint Research Centre Available from: 〈http://ies.jrc.ec.europa.eu/our-activ ities/support-to-eu-policies/well-to-wheels-analysis/WTW.html $\rangle$.

EEA, 2009a. Greenhouse gas emission trends and projections in Europe 2009. EEA Report, European Environmental Agency. Available from: 〈http://www.eea. europa.eu/publications/eea_report_2009_9>.

EEA, 2009b. Indicators-Transport-EEA. Available from: <http://www.eea. europa.eu/themes/transport/indicators\#AAAAAAAEFEI $=>$ (accessed 20.04.09).

EIA, 2009a. Gas and Diesel Fuel Update. 〈http://tonto.eia.doe.gov/oog/info/gdu/ gasdiesel.asp > (accessed 05.09).

EIA, 2009b. A Primer on Gasoline Prices. Available from: 〈http://www.eia.doe.gov/ bookshelf/brochures/gasolinepricesprimer/>.

EU, 2009. Directive on the promotion of the use of energy from renewable sources, 2009/28/EC. Official Journal of the European Union Available from: $<$ http://eur-lex europa.eu/LexUriServ/LexUriServ.do?uri=OJ:L:2009:140:0016:0062:EN:PDF $\rangle$.

EurObserv'ER, 2006. Biofuels Barometer. Systèmes Solaires. Available from: 〈http:// www.energies-renouvelables.org/observ-er/stat_baro/observ/baro173b.pdf $\rangle$.

EurObserv'ER, 2009. Biofuels Barometer. Systèmes Solaires. Available from: $\langle$ http://www.eurobserv-er.org/pdf/baro192.pdf 〉.

European Commission, 2008. 2020 by 2020_Europe's climate change opportunity. Available from: 〈http://eur-lex.europa.eu/LexUriServ/LexUriServ.do?uri= CELEX:52008DC0030:EN:NOT $\rangle$. 
Everts, D.-J., 2008. Energy Use and $\mathrm{CO}_{2}$ Emissions of Bitumen and Oil Shale Based Liquid Fuel Production-Explorations in TIMER, Science, Technology and Scoiety. Utrecht University, Utrecht.

Farla, J., Mulder, M., Verrips, A., Gordijn, H., Menkveld, M., Dril, T.v., Volkers, C., de Joode, J., Seebregts, A., Daniëls, B., Boerakker, Y., Stienstra, G., Beurskens, L., Kroon, P., Janssen, L., Okker, R., Schuur, J., 2008. Welvaart en Leefomgeving: Energie. Energieonderzoek Centrum Nederland, Centraal Planbureau, MilieuNatuur Planbureau, Ruimtelijk Planbureau, 978-90-6960-149-6. Available from:〈http://www.welvaartenleefomgeving.nl/energie.html >.

Fulton, L., Eads, G., 2004. Sustainable mobility project spreadsheet model. IEA Available from: $\langle$ http://www.wbcsd.org/plugins/DocSearch/details.asp?type= DocDet\&ObjectId=MTEONjc $\rangle$.

Goldemberg, J., 2009. Ethanol for a sustainable energy future. Science 315 (5813), 808-810 Available from:〈http://dx.doi.org/10.1126/science.1137013〉.

Grahn, M., Azar, C., Williander, M.I., Anderson, J.E., Mueller, S.A., Wallington, T.J., 2009. Fuel and Vehicle technology choices for passenger vehicles in achieving stringent $\mathrm{CO}_{2}$ targets: connections between transportation and other energy sectors. Environmental Science and Technology 43 (9), 3365-3371 Available from: $\langle$ http://dx.doi.org/10.1021/es802651r $\rangle$.

Gül, T., Kypreos, S., Turton, H., Barreto, L., 2009. An energy-economic scenario analysis of alternative fuels for personal transport using the global multi-regiona MARKAL model (GMM). Energy 34 (10), 1423-1437 Available from: 〈http://dx doi.org/10.1016/j.energy.2009.04.010>

Hamelinck, C.N., Faaij, A.P.C., 2002. Future prospects for production of methanol and hydrogen from biomass. Journal of Power Sources 111 (1) 1-22 Available from:〈http://dx.doi.org/10.1016/S0378-7753(02)00220-3〉.

Hamelinck, C.N., Faaij, A.P.C., 2006. Outlook for advanced biofuels. Energy Policy 34 (17), 3268-3283 Available from: 〈http://dx.doi.org/10.1016/j.enpol.2005. $06.012>$.

Hamelinck, C.N., van Hooijdonk, G., Faaij, A.P.C., 2005. Ethanol from lignocellulosic biomass: techno-economic performance in short-, middle- and long-term. Biomass and Bioenergy 28 (4), 384-410 Available from: 〈http://dx.doi. org/10.1016/j.biombioe.2004.09.002 >.

Hedenus, F., Karlsson, S., Azar, C., Sprei, F., 2010. Cost-effective energy carriers for transport-the role of the energy supply system in a carbon-constrained world. International Journal of Hydrogen Energy 35 (10), 4638-4651 Available from: 〈http://dx.doi.org/10.1016/j.ijhydene.2010.02.064〉.

Hendriks, C., Hagedoorn, S., Warmenhoven, H., 2007. Transportation of Carbon Dioxide and Organisational Issues of CCS in the Netherlands, Spinconsult, Utrecht. Ecofys.

Hendriks, C., Wildenborg, T., Feron, P., Graus, W., Brandsma, R., 2003. EC-CASE Carbon Dioxide Sequestration. Ecofys, TNO, Utrecht, M70066.

Hendriks, F.H.J.F., Hekkert, M.P., Faaij, A.P.C., Neelis, M.L., 2005. Natural gas as an alternative to crude oil in automotive fuel chains well-to-wheel analysis an transition strategy development. Energy Policy 33 (5), 579-594 Available from:〈http://dx.doi.org/10.1016/j.enpol.2003.08.018〉.

Hoefnagels, R., Dornburg, V., Faaij, A.P.C., Banse, M., 2009. Analysis of the economic impact of large-scale deployment of biomass resources for energy and materials in the Netherlands. Macro-economics Biobased Synthesis Report. Natuurwetenschap \& Samenleving, UU with Landbouw Economisch Instituut, Utrecht Available from: 〈http://www.lei.wur.nl/NR/rdonlyres/EDE77C 44-77FF-4BBC-B4CC-84C93FDACABE/82298/00_Macroeconomics_biobased synthesisreport.pdf $>$.

Hoogwijk, M.M., Faaij, A.P.C., de Vries, B.J.M., Turkenburg, W.C., 2009. Exploration of regional and global cost-supply curves of biomass energy from shortrotation crops at abandoned cropland and rest land under four IPCC SRES landuse scenarios. Biomass and Bioenergy 33 (1), 26-43 Available from: 〈http: //dx.doi.org/10.1016/j.biombioe.2008.04.005 >.

Ichinohe, M., Endo, E., 2006. Analysis of the vehicle mix in the passenger-car sector in Japan for $\mathrm{CO}_{2}$ emissions reduction by a MARKAL model. Applied Energy 83 (10), 1047-1061 Available from: 〈http://dx.doi.org/10.1016/j.apenergy. 2005.08.002>.

IEA, 2004. Biofuels for Transport-An International Perspective. International Energy Agency, Paris, FR.

IEA, 2007. World Energy Outlook 2007 China India Insights. International Energy Agency, Paris, FR Available from: <http://www.worldenergyoutlook.org/2007. asp $>$.

IEA, 2008a. Energy Technology Perspectives 2008. International Energy Agency, Paris, FR.

IEA, 2008b. World Energy Outlook 2008 Edition. International Energy Agency, Paris, FR.

IEA, 2009. World Energy Outlook 2009 Edition. International Energy Agency, Paris, FR

IEA, 2010. Energy Technology Perspectives 2010. International Energy Agency, Paris, FR.

Iowa Department of Transportation, 2009. A primer on fuel prices. Available from: $\langle$ http://www.iowadot.gov/time21/images/issue_paper.pdf $\rangle$.

Janssen, L., Okker, R., Schuur, J., 2008. Welvaart en Leefomgeving: Scenario's. Centraal Planbureau, Milieu-Natuur Planbureau, Ruimtelijk Planbureau, 978-90-6960-149-6. Available from: 〈http://www.welvaartenleefomgeving. $\mathrm{nl} /$ scenario.html $>$.

Johansson, T.B., Goldemberg, J., 2004. World Energy Assessment. United Nations Development Programme, New York, NY, USA.

Junginger, M., de Visser, E., Hjort-Gregersen, K., Koornneef, J., Raven, R., Faaij, A.P.C., Turkenburg, W.C., 2005. Technological learning in bioenergy systems.
Energy Policy 34 (18), 4024-4041 Available from: 〈http://dx.doi.org/ 10.1016/j.enpol.2005.09.012

Kintner-Meyer, M., Schneider, K., Pratt, R., 2007. Impacts Assessment of Plug-in Hybrid Vehicles on Electric Utilities and Regional US Power Grids. Pacific Northwest National Laboratory, Richland, WA, USA Available from: <http:// www.ferc.gov $>$.

Kramers, L., Leverink, D., Benedictus, T., van Gessel, S., Geel, C., Simmelink, E., Echternach, M., Hofstee, C., Pagnier, H., 2007. Geological Screening of Aquifer Traps and Wintershall Gas Fields for $\mathrm{CO}_{2}$ Injection Purposes in the Netherlands. TNO, Utrecht (confidential).

Lako, P., Seebregts, A.J., 1998. Characterisation of Power Generation Options for the 21st Century: Report On Behalf of Macro Task E1. ECN Beleidsstudies, Petten, NL, ECN-C-98-085. Available from:〈http://www.ecn.nl/publicaties/default. aspx? $\mathrm{nr}=\mathrm{ECN}-\mathrm{C}-98-085>$

Larson, E.D., Jin, H., Celik, F., 2005. Gasification-Based fuels and electricity production from biomass, without and with carbon capture and storage. In: Fourth Annual Conference on Carbon Capture and Sequestration, Alexandria, VA, US.

LBST, 2007. HyWays - an integrated project to develop the European hydrogen energy roadmap. Available from: 〈http://www.hyways.de/ $\rangle$.

LBST, 2008. European hydrogen energy roadmap hyways. Available from: <http:/ www.hyways.de/docs/Brochures_and_Flyers/HyWays_Roadmap_FINAL_22 FEB2008.pdf $>$.

Macedo, I.C., 2008. GHG emissions in the production and use of ethanol from sugarcane in Brazil. Available from:〈http://www.braseuropa.be/Seminar\%20 EU\%20Sustainability\%20Requirements\%20a\%20Challenge\%20for\%20Brazilian\% 20Ethanol\%20Brussels\%207\%200ctober\%202008/081007\%20Isaias\%20MACEDO. ppt > (accessed 07.10.09).

Mercedes-Benz, Omnibusse, 2008. Citaro BlueTec ${ }^{\mathbb{R}}$-altijd een idee vooruit EvoBus GmbH, Mannheim, DE.

Ministerie van Financiën, 2009. Milieubelastingen. Available from: 〈http://www. minfin.nl/Onderwerpen/Milieu $>$.

Mitchell, J.V., 2006. A new Era for Oil Prices. Chatham House (Royal Institute of International Affairs), London.

oanda.com, 2007. FXHistory-historical currency exchange rates. Available from: $\langle$ http://www.oanda.com/convert/fxhistory > (accessed 03.07).

Ogden, J.M., Steinbugler, M.M., Kreutz, T.G., 1999. A comparison of hydrogen, methanol and gasoline as fuels for fuel cell vehicles: implications for vehicle design and infrastructure development. Journal of Power Sources 79 (2), 143-168 Available from: <http://dx.doi.org/10.1016/S0378-7753(99) 00057-9>.

pellets@tlas, 2009. Pellet market data. Available from:〈http://www.pelletsatlas. info/>.

Pershad, H., Slater, S., 2007. Development of a $\mathrm{CO}_{2}$ transport and storage network in the North Sea. Report to the North Sea Basin Task Force. Department for Business, Energy and Regulatory Reform in association with Element Energy Ltd. with Pöyry Energy and the British Geological Survey. Available from: $\langle$ http://www.berr.gov.uk/files/file42476.pdf $\rangle$.

Proost, S., Delhaye, E., Nijs, W., Regemorter, D.V., 2009. Will a radical transport pricing reform jeopardize the ambitious EU climate change objectives? Energy Policy 37 (10) 3863-3871 Available from:〈http://dx.doi.org/10.1016/j.enpol. 2009.07.023>.

Ragwitz, M., Schade, W., Breits, B., chopf, , Walz, R., Helfrich, N., Rathmann, M., Resch, G., Panzer, C., Faber, T., Haas, R., Nathani, C., Holzhey, M., Konstantinaviciute, I., Zagame', P., Fougeyrollas, A. Le Hir, B., 2009. EmployRES-the impact of renewable energy policy on economic growth and employment in the European Union. Fraunhofer ISI, Ecofys, Energy Economics Group (EEG), Rütter+Partner Socioeconomic Research + Consulting, Lithuanian Energy Institute (LEI), Socie'te' Europe'enne d'E'conomie (SEURECO), Karlsruhe. Available from: 〈http://ec.europa.eu/energy/renewables/studies/doc/renewables/ 2009_employ_res_report.pdf $\rangle$.

Ramírez, A., Hagedoorn, S., Kramers, L., Wildenborg, T., Hendriks, C., 2009. Screening $\mathrm{CO}_{2}$ storage options in the Netherlands. Energy Procedia 1 (1), 2801-2808 Available from:〈http://dx.doi.org/10.1016/j.egypro.2009.02.052〉.

Schotman, G., 2009. BioSNG Production Chains: Chain Analysis for different BioSNG Production Locations Comparing Biomass and Gas Transport Science, Technology and Society. Universiteit Utrecht, Utrecht, p. 54.

Serbutoviez, S., Coussy, P., Lokhorst, A., Keppel, F., Kramers, L., van der Kuip, M.D.C., Egberts, P.J.P., 2007. Economic Analysis Tool. Deliverable 1.1.3B. CASTOR Project.

Shell Nederland, 2008. Hoe zijn Shell brandstofprijzen opgebouwd? Available from: 〈http://www.shell.nl/home/content/nld/products_services/on_the_road/fuels/fuel_ pricing/cpp/pricestructure/structure.html $\rangle$ (accessed 28.10.08).

Sjardin, M., Damen, K.J., Faaij, A.P.C., 2006. Techno-economic prospects of small-scale membrane reactors in a future hydrogen-fuelled transportation sector. Energy 31 (14), 2523-2555 Available from: 〈http://dx.doi.org/10.1016/j.energy.2005. $12.004>$.

Smeets, E., Faaij, A.P.C., Lewandowski, I., 2010. The impact of sustainability criteria on the costs and potentials of bioenergy production - applied for case studies in Brazil and Ukraine. Biomass and Bioenergy 34 (3), 319-333 Available from:〈http://dx.doi.org/10.1016/j.biombioe.2009.11.003〉.

Smeets, E., Junginger, M., Faaij, A., Walter, A., Dolzan, P., Turkenburg, W., 2008. The sustainability of Brazilian ethanol-an assessment of the possibilities of certified production. Biomass and Bioenergy 32 (8), 781-813 Available from: $\langle$ http://dx.doi.org/10.1016/j.biombioe.2008.01.005〉. 
Smekens-Ramirez Morales, K.E.L., 2004. Response from a MARKAL technology model to the EMF scenario assumptions. Energy Economics 26 (4), 655-674 Available from:〈http://dx.doi.org/10.1016/j.eneco.2004.04.032〉.

Smekens, K.E.L., 2005. Technology R\&D and $\mathrm{CO}_{2}$ policy scenarios. The MARKAL model work for SAPIENTIA. ECN beleidsstudies, Petten, NL, ECN-C-05-059. Available from: $\langle$ http://www.ecn.nl/publicaties/default.aspx?nr=ECN-C-05-059〉.

Strachan, N., Balta-Ozkan, N., Joffe, D., McGeevor, K., Hughes, N., 2008. Soft-linking energy systems and GIS models to investigate spatial hydrogen infrastructure development in a low-carbon UK energy system. International Journal of Hydrogen Energy 34 (2), 642-657 Available from: 〈http://dx.doi. org/10.1016/j.ijhydene.2008.10.083 >.

Strachan, N., Kannan, R., 2008. Hybrid modelling of long-term carbon reduction scenarios for the UK. Energy Economics 30 (6), 2947-2963 Available from: 〈http://dx.doi.org/10.1016/j.eneco.2008.04.009〉.

TenneT, 2008. 10 jaar landelijk netbeheer-TenneT in stroomversnelling. TenneT, Arnhem. Available from: 〈http://tennet.ireports.nl/documenten/tennet_nl_ lange_versie_26_mei.pdf $\rangle$.

TNO, 2007a. Extraction plans of all hydrocarbon fields. Available from: 〈http:// www.nlog.nl/nl/procs/procedures_plans.html $>$.

TNO, 2007b. Options for $\mathrm{CO}_{2}$ storage in the Netherlands-time dependent storage capacity, hazard aspects, and regulations. TNO Built Environment and Geosciences, Utrecht.

TNO, 2007c. Overview of the coordinates of all hydrocarbon fields. Available from: 〈http://www.nlog.nl/dinoLks/requestData/nlogp/allBor/listing.jsp?menu=act 〉.

Torp, T., 2008. Costs for $\mathrm{CO}_{2}$ storage in the Utsira formation, personal communication to van den Broek, $\mathrm{M}$.

UKERC, 2008. UK MARKAL Model: Documentation. Available from: 〈http://www. ukerc.ac.uk $>$.

Uslu, A., Faaij, A.P.C., Bergman, P.C.A., 2008. Pre-treatment technologies, and their effect on international bioenergy supply chain logistics. Techno-economic evaluation of torrefaction, fast pyrolysis and pelletisation. Energy 33 (8), 1206-1223 Available from:〈http://dx.doi.org/10.1016/j.energy.2008.03.007〉.

van Beek, F., Flikkema, H., Francke, J., Besseling, P., Groot, W., Nijland, H., Ritsema van Eck, J., Janssen, L., Okker, R., Schuur, J., 2008. Welvaart en Leefomgeving: Mobiliteit. Adviesdienst Verkeer en Vervoer, Centraal Planbureau, MilieuNatuur Planbureau, Ruimtelijk Planbureau, 978-90-6960-149-6. Available from: 〈http://www.welvaartenleefomgeving.nl/mobiliteit.html $\rangle$.

van den Broek, M., Brederode, E., Ramírez, A., Kramers, L., van der Kuip, M., Wildenborg, T., Faaij, A., Turkenburg, W., 2009. A GIS/MARKAL tool to design a $\mathrm{CO}_{2}$ infrastructure in line with the development of the energy supply system. Energy Procedia 1 (1), 4071-4078 Available from: 〈http://dx.doi.org/ 10.1016/j.egypro.2009.02.214>.

van den Broek, M., Faaij, A., Turkenburg, W., 2008. Planning for an electricity sector with carbon capture and storage: case of the Netherlands. International Journal of Greenhouse Gas Control 2 (1), 105-129 Available from: 〈http://dx doi.org/10.1016/S1750-5836(07)00113-2 >.

van den Broek, M., Ramírez, A., Groenenberg, H., Neele, F., Viebahn, P., Turkenburg, W., Faaij, A. Feasibility of storing $\mathrm{CO}_{2}$ in the Utsira formation as part of a long term Dutch CCS strategy. International Journal of Greenhouse Gas Control, in press. Available from: 〈http://dx.doi.org/10.1016/j.ijggc.2009.09.002 〉.

van den Wall-Bake, J.D., Junginger, M., Faaij, A.P.C., Poot, T., da Silva Walter, A., 2009. Explaining the experience curve: cost reductions of Brazilian ethanol from sugarcane. Biomass and Bioenergy 33 (4), 644-658 Available from:〈http://dx.doi.org/10.1016/j.biombioe.2008.10.006 〉.

van Vliet, O.P.R., Brouwer, A.S., Kuramochi, T., van den Broek, M., Faaij, A.P.C Energy use, cost and $\mathrm{CO}_{2}$ emissions of electric cars, in press-a. Available from: $\langle$ http://dx.doi.org/10.1016/j.jpowsour.2010.09.119〉.

van Vliet, O.P.R., Faaij, A.P.C., Turkenburg, W.C., 2009. Fischer-Tropsch diesel production in a well-to-wheel perspective: a carbon, energy flow and cost analysis. Energy Conversion and Management Available from: $<$ http://dx.doi. org/10.1016/j.enconman.2009.01.008 >.

van Vliet, O.P.R., Kruithof, T., Faaij, A.P.C. Techno-economic comparison of series hybrid, fuel cell and regular cars. Journal of Power Sources, in press-b. Available from: 〈http://dx.doi.org/10.1016/j.jpowsour.2010.04.077〉.

VROM, 2006. Ontwerp-convenant kerncentrale Borssele. Available from: 〈http:// www.vrom.nl/get.asp?file=docs/kamerstukken/Tue10Jan20061132230100/ TK-KCB-bijlage-Convenant-9jan2006.pdf. $>$.

WBCSD, 2004. Mobility 2030: Meeting the Challenges to Sustainability. World Business Council for Sustainable Development, Conches-Geneva.

Weiss, M., Heywood, J., Drake, E., Schafer, A., AuYeung, F., 2000. On the Road in 2020: A Life-Cycle Analysis of New Automobile Technologies. Massachusetts Institute of Technology, Laboratory for Energy and the Environment, Cambridge, MA, USA EL 00-003.

Wene, C.-O., 2000. Experience Curves for Energy Technology Policy. International Energy Agency.

Wildenborg, A.F.B., Neele, F.P., Kramers, L., 2008. Supplement on Report 1.1.3B-Economic Analysis Tool. Deliverable 1.1.5B. CASTOR Project (not publicly available).

Wise, M., Kyle, G.P., Dooleya, J.J., Kim, S.H., 2010. The impact of electric passenger transport technology under an economy-wide climate policy in the United States: carbon dioxide emissions, coal use, and carbon dioxide capture and storage. International Journal of Greenhouse Gas Control 4 (2) 301-308 Available from:〈http://dx.doi.org/10.1016/j.ijggc.2009.09.003〉.

Zittel, W., Schindler, J., 2004. The countdown for the peak of oil production has Begun - but what are the views of the most important international energy agencies, EnergyBulletin.net. L-B-Systemtechnik, p. 21. 